\title{
Linking Pulmonary Oxygen Uptake, Muscle Oxygen Utilization and Cellular Metabolism during Exercise
}

\author{
Nicola Lai, ${ }^{1,2,3}$ Marco Camesasca, ${ }^{2,4}$ Gerald M. Saidel, ${ }^{1,3}$ Ranjan K. Dash, ${ }^{2,3}$ and Marco \\ E. CABRERA $1,2,3,4,5$
}

\begin{abstract}
${ }^{1}$ Biomedical Engineering, Case Western Reserve University, Cleveland, OH USA; ${ }^{2}$ Department of Pediatrics, Case Western Reserve University, Cleveland, OH USA; ${ }^{3}$ Center for Modeling Integrated Metabolic Systems, Case Western Reserve University, Cleveland, OH USA; ${ }^{4}$ Rainbow Babies and Children's Hospital, Cleveland, OH USA; and ${ }^{5}$ Pediatric Cardiology, MS-6011, Case Western Reserve University, 11100 Euclid Avenue, RBC 389, Cleveland, OH 44106-6011, USA
\end{abstract}

(Received 2 November 2006; accepted 25 January 2007; published online 23 March 2007)

\begin{abstract}
The energy demand imposed by physical exercise on the components of the oxygen transport and utilization system requires a close link between cellular and external respiration in order to maintain ATP homeostasis. Invasive and non-invasive experimental approaches have been used to elucidate mechanisms regulating the balance between oxygen supply and consumption during exercise. Such approaches suggest that the mechanism controlling the various subsystems coupling internal to external respiration are part of a highly redundant and hierarchical multi-scale system. In this work, we present a "systems biology" framework that integrates experimental and theoretical approaches able to provide simultaneously reliable information on the oxygen transport and utilization processes occurring at the various steps in the pathway of oxygen from air to mitochondria, particularly at the onset of exercise. This multi-disciplinary framework provides insights into the relationship between cellular oxygen consumption derived from measurements of muscle oxygenation during exercise and pulmonary oxygen uptake by indirect calorimetry. With a validated model, muscle oxygen dynamic responses is simulated and quantitatively related to cellular metabolism under a variety of conditions.
\end{abstract}

Keywords-Cellular metabolism, Modeling, Multi-scale approach, Oxygen transport, Oxidative phosphorylation, Systems biology.

\section{LIST OF SYMBOL}

$\begin{array}{ll}C_{\mathrm{A}, \text { tot }} & \begin{array}{l}\text { Total concentration of ADP and ATP } \\ (\mathrm{mM})\end{array} \\ C_{\mathrm{ADP}} & \text { Concentration of ADP in tissue }(\mathrm{mM}) \\ C_{\mathrm{ATP}} & \text { Concentration of ATP in tissue }(\mathrm{mM})\end{array}$

Address correspondence to Marco

E. Cabrera, Pediatric Cardiology, MS-6011, Case Western Reserve University, 11100 Euclid Avenue, RBC 389, Cleveland, OH 441066011, USA. Electronic mail: mec6@cwru.edu

\begin{tabular}{|c|c|}
\hline$C_{\mathrm{Cr} \text {,tot }}$ & $\begin{array}{l}\text { Total Concentration of } \mathrm{PCr} \text { and } \mathrm{Cr} \\
(\mathrm{mM})\end{array}$ \\
\hline$C_{\mathrm{Cr}}$ & Concentration of $\mathrm{Cr}$ in tissue (mM) \\
\hline$C_{\mathrm{PCr}}$ & Concentration of $\mathrm{PCr}$ in tissue (mM) \\
\hline$C_{\mathrm{rbc}, \mathrm{Hb}}$ & $\begin{array}{l}\text { Concentration of } \mathrm{Hb} \text { in the red blood } \\
\text { cell }(\mathrm{mM})\end{array}$ \\
\hline$C_{\mathrm{mc}, \mathrm{Mb}}$ & Concentration of $\mathrm{Mb}$ in myocyte $(\mathrm{mM})$ \\
\hline$C_{\mathrm{x}}^{\mathrm{B}}$ & $\begin{array}{l}\text { Bound oxygen concentration in artery, } \\
\text { capillary and tissue }(\mathrm{mM})\end{array}$ \\
\hline$C_{\mathrm{x}}^{\mathrm{F}}$ & $\begin{array}{l}\text { Free oxygen concentration in artery, } \\
\text { capillary and tissue }(\mathrm{mM})\end{array}$ \\
\hline$C_{\mathrm{x}}^{\mathrm{T}}$ & $\begin{array}{l}\text { Total oxygen concentration in artery, } \\
\text { capillary and tissue }(\mathrm{mM})\end{array}$ \\
\hline Hct & $\begin{array}{l}\text { Hematocrit (fraction of red blood cells } \\
\text { in blood) (-) }\end{array}$ \\
\hline$k_{\mathrm{ATPase}}$ & ATPase rate constant $\left(\mathrm{min}^{-1}\right)$ \\
\hline$K_{\mathrm{Hb}}$ & $\begin{array}{l}\text { Hill constant at which } \mathrm{Hb} \text { is } 50 \% \text { satu- } \\
\text { rated by } \mathrm{O}_{2}\left(\mathrm{mM}^{-\mathrm{n}}\right)\end{array}$ \\
\hline$K_{\mathrm{Mb}}$ & $\begin{array}{l}\text { Hill constant at which } \mathrm{Mb} \text { is } 50 \% \text { sat- } \\
\text { urated by } \mathrm{O}_{2}\left(\mathrm{mM}^{-1}\right)\end{array}$ \\
\hline$K_{\mathrm{ADP}}$ & CK constant $(\mathrm{mM})$ \\
\hline$K_{\mathrm{b}}$ & CK constant (mM) \\
\hline$K_{\mathrm{ia}}$ & CK constant (mM) \\
\hline$K_{\mathrm{ib}}$ & CK constant (mM) \\
\hline$K_{\mathrm{iq}}$ & CK constant (mM) \\
\hline$K_{\mathrm{m}}$ & Michaelis Menten constant (mM) \\
\hline$K_{\mathrm{p}}$ & CK constant $(\mathrm{mM})$ \\
\hline$n$ & Hill coefficient $(-)$ \\
\hline PS & $\begin{array}{l}\text { Permeability-surface area product } \\
\left(\mathrm{L} \min ^{-1}\right)\end{array}$ \\
\hline $\mathrm{PS}^{\mathrm{E}}$ & $\begin{array}{l}\text { Maximal value of permeability-surface } \\
\text { area product }\left(\mathrm{L} \min ^{-1}\right)\end{array}$ \\
\hline $\mathrm{PS}^{\mathrm{R}}$ & $\begin{array}{l}\text { Permeability-surface area product at } \\
\text { rest }\left(\mathrm{L} \min ^{-1}\right)\end{array}$ \\
\hline$Q_{\mathrm{C}}$ & $\begin{array}{l}\text { Muscle blood flow constant in Eq. (13) } \\
(\mathrm{L} \mathrm{min}-1)\end{array}$ \\
\hline$Q_{\mathrm{m}}$ & Muscle blood flow $\left(\mathrm{L} \min ^{-1}\right)$ \\
\hline
\end{tabular}




\begin{tabular}{|c|c|}
\hline$S_{\text {cap }, \mathrm{Hb}}$ & $\begin{array}{l}\text { Oxygen hemoglobin saturation in blood } \\
\text { capillary }(-)\end{array}$ \\
\hline$S_{\mathrm{tis}, \mathrm{Mb}}$ & $\begin{array}{l}\text { Oxygen myoglobin saturation in muscle } \\
\text { tissue }(-)\end{array}$ \\
\hline $\mathrm{StO}_{2 \mathrm{~m}}$ & Muscle oxygen saturation (-) \\
\hline$T_{\mathrm{m}}$ & Total amount of $\mathrm{Hb}$ and $\mathrm{Mb}(\mathrm{mmol})$ \\
\hline$t$ & Time $(\min )$ \\
\hline$t^{\mathrm{W}}$ & Time at the onset of the exercise (min) \\
\hline $\mathrm{UO}_{2 \mathrm{~m}}$ & Muscle oxygen utilization $\left(\mathrm{mmol} \mathrm{min}^{-1}\right)$ \\
\hline$V_{\mathrm{CK}}^{\mathrm{f}}$ & $\begin{array}{l}\text { Maximal forward flux of CK reaction } \\
\left(\mathrm{mM} \mathrm{min}^{-1}\right)\end{array}$ \\
\hline$V_{\mathrm{CK}}^{\mathrm{r}}$ & 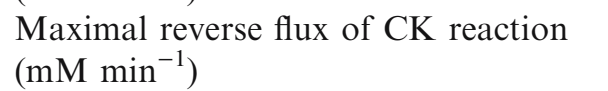 \\
\hline$V_{\max }$ & $\begin{array}{l}\text { Maximal flux of oxidative Phosphory- } \\
\text { lation }\left(\mathrm{mM} \mathrm{min}^{-1}\right)\end{array}$ \\
\hline$V_{\text {cap }}, V_{\text {tis }}$ & $\begin{array}{l}\text { Anatomical volume of capillary and } \\
\text { tissue (L) }\end{array}$ \\
\hline $\mathrm{VO}_{2 \mathrm{~m}}, \mathrm{VO}_{2 \mathrm{p}}$ & 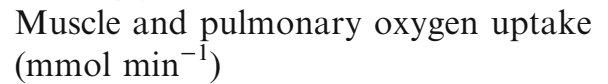 \\
\hline WR & Work rate (watt) \\
\hline$W_{\mathrm{mc}}$ & Myocyte volume fraction (-) \\
\hline$\Delta \mathrm{PS}$ & $\begin{array}{l}\text { Amplitude of permeability-surface area } \\
\left(\mathrm{L} \mathrm{min}^{-1}\right)\end{array}$ \\
\hline$\Delta Q_{\mathrm{m}}$ & $\begin{array}{l}\text { Amplitude of response of muscle blood } \\
\text { flow rate }(\mathrm{L} \mathrm{min}-1)\end{array}$ \\
\hline
\end{tabular}

\section{Greek letters}

\begin{tabular}{|c|c|}
\hline$\phi_{\text {ATPase }}$ & ATPase metabolic flux $\left(\mathrm{mM} \min ^{-1}\right)$ \\
\hline$\phi_{\mathrm{CK}}^{\mathrm{f}}$ & 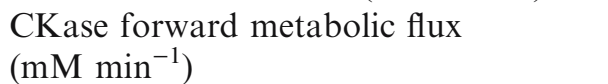 \\
\hline$\phi_{\mathrm{CK}}^{\mathrm{r}}$ & $\begin{array}{l}\text { CKase reverse metabolic flux } \\
\left.(\mathrm{mM} \mathrm{min})^{-1}\right)\end{array}$ \\
\hline$\phi_{\text {OxPhos }}$ & $\begin{array}{l}\text { Oxydative phosphorylation metabolic } \\
\text { flux }\left(\mathrm{mM} \min ^{-1}\right)\end{array}$ \\
\hline$\tau_{\mathrm{PCr}}$ & Time constant of the PCr kinetics (s) \\
\hline$\tau_{\text {Power }}$ & $\begin{array}{l}\text { Time constant of the mechanical power } \\
\text { (s) }\end{array}$ \\
\hline$\tau_{Q_{\mathrm{m}}}$ & $\begin{array}{l}\text { Time constant of the muscle blood flow } \\
\text { (s) }\end{array}$ \\
\hline$\tau_{\mathrm{UO}_{2 \mathrm{~m}}}$ & $\begin{array}{l}\text { Time constant of the muscle oxygen } \\
\text { utilization (s) }\end{array}$ \\
\hline$\tau_{\mathrm{VO}_{2 \mathrm{~m}}}$ & $\begin{array}{l}\text { Mean response time of the muscle oxy- } \\
\text { gen uptake (s) }\end{array}$ \\
\hline$\tau_{\mathrm{VO}_{2 \mathrm{p}}}$ & $\begin{array}{l}\text { Mean response time of the pulmonary } \\
\text { oxygen uptake (s) }\end{array}$ \\
\hline
\end{tabular}

\section{Superscript}

$\begin{array}{ll}\text { B } & \text { Bound oxygen concentration } \\ \mathrm{F} & \text { Free oxygen concentration } \\ \mathrm{H} & \text { Heavy condition } \\ \mathrm{j} & \text { Exercise intensity } \\ \mathrm{M} & \text { Moderate condition } \\ \mathrm{R} & \text { Resting condition }\end{array}$

$\begin{array}{ll}\text { T } & \text { Total oxygen concentration } \\ \mathrm{V} & \text { Very heavy condition } \\ \mathrm{W} & \text { Warm-up condition }\end{array}$

\section{INTRODUCTION}

The energy demand imposed by physical exercise on the components of the oxygen transport and utilization system requires a close link between cellular and external respiration in order to maintain adenosine triphosphate (ATP) homeostasis. At the onset of exercise, an immediate increase in the rate of production of (ATP) in active skeletal muscle fibers is required to meet the increased rate of ATP utilization (metabolic demand). Mechanical power output of muscle measured on a cycle ergometer - responds quickly $\left(\tau_{\text {Power }}<2\right.$ s to a step change in work rate, indicating an even faster response of the ATP production rate by contracting muscles. In contrast, the corresponding dynamic responses of pulmonary oxygen uptake $\left(\mathrm{VO}_{2 \mathrm{p}}\right)$ and muscle oxygen uptake $\left(\mathrm{VO}_{2 \mathrm{~m}}\right)^{29,38,47,50,55}$ are much slower $\left(\tau_{\mathrm{VO}_{2}} \sim 30 \mathrm{~s}\right)$. This slower response reflects the ATP production rate from oxidation of reducing equivalents in active muscle. While the steady states for ATP demand and ATP supply through oxidative metabolism match perfectly after $\sim 2-3$ min at submaximal work rates, their transient responses differ by at least an order of magnitude.

Noninvasive measurements of $\mathrm{VO}_{2 \mathrm{p}}$ dynamics can characterize differences in onset kinetics of healthy and chronically ill individuals. ${ }^{7,8,49}$ These measurements, however, not only reflect cellular metabolism, but also the effect of components of the delivery system that transports oxygen from the external environment to the mitochondria (e.g., pulmonary ventilation, diffusion from alveoli to blood, transport in blood - dissolved and bound to hemoglobin - to tissues, diffusion from blood to cells). Because measurements of $\mathrm{VO}_{2 \mathrm{p}}$ dynamics do not accurately indicate the cellular $\mathrm{O}_{2}$ availability and utilization rate in contracting muscle, they are insufficient for deducing mechanisms of metabolic control at the cellular level.

To investigate factors controlling the rate of pulmonary oxygen uptake at exercise onset, oxygen uptake has been measured directly across the femoral bed during cycling in humans ${ }^{29}$ and across isolated whole skeletal muscle preparations in dogs. ${ }^{24-27,29}$ These whole-muscle studies have provided valuable insights about the effect of altering convective oxygen delivery and peripheral oxygen diffusion on the dynamics of muscle oxygen uptake during moderate and heavy intensity exercise. Nevertheless, they also have some inherent limitations. When a whole muscle is stimulated in lieu of voluntary muscle contraction, the fiber- 
type recruitment pattern is different. Furthermore, controlling bulk oxygen delivery does not necessarily control the matching of perfusion to metabolism. Measurements of the oxygen content in the arterial and venous blood do not reflect the actual amount of oxygen available at the mitochondrial level. Local oxygen availability (i.e., cellular $\mathrm{PO}_{2}$ ) in intact muscle tissue is difficult to assess during exercise in these whole-tissue preparations.

Cellular oxygen availability can be assessed in muscle of contrasting fiber types with phosphorescence quenching ${ }^{9}$ or in intact working muscle with either nearinfrared spectroscopy ${ }^{28}$ or ${ }^{1} \mathrm{H}$ magnetic resonance spectroscopy. ${ }^{36,60}$ However, these methods lack specificity when measuring the dynamics of cellular oxygen consumption in a large muscle group during exercise. Nevertheless, intracellular oxygen consumption can be estimated using ${ }^{31} \mathrm{P}$ magnetic resonance spectroscopy by using $\mathrm{PCr}$ dynamics as a proxy (within $10 \%$ ) to muscle oxygen consumption dynamics. ${ }^{3,53,54,65}$ A more suitable approach to investigate mechanisms controlling respiration is to conduct simultaneous measurements of putative intramuscular control mediators $(\mathrm{PCr}, \mathrm{Cr}, \mathrm{Pi}$, ATP, ADP) dynamics and $\mathrm{VO}_{2 p}$ dynamics while performing exercise involving a large muscle group (e.g., quadriceps). This approach provides a large change in $\mathrm{VO}_{2 p}$ at exercise onset and reliable $\mathrm{VO}_{2 p}$ dynamic responses which can be compared to those of $\mathrm{PCr}{ }^{53,65}$

Even if measurements at each scale (i.e., organelle, cellular, tissue/organ, and whole organism level) were experimentally feasible with the appropriate time resolution, these must be integrated into a coordinated system for data interpretation and for elucidation of mechanisms of metabolic control and regulation. For quantitative understanding, integration of transport and metabolic processes at the cellular, tissue/organ, and whole-body levels requires a formal theoretical framework. As a complement to experimental studies of oxygen uptake/consumption at various exercise intensities and biological levels, we used a mathematical model to integrate data and to simulate responses at the cellular and tissue level. The models integrated in this study have been validated previously. ${ }^{42,62}$

The "systems biology" approach employed here in linking external to internal respiration uses both experimental data from non-invasive methods and computational models to understand complex phenomena and biological systems underlying physiological function and ATP homeostasis. For initial model development to analyze exercise responses, we used data at the whole body and tissue level. In addition, we measured pulmonary oxygen uptake (indirect calorimetry) and muscle oxygenation (near-infrared spectroscopy) dynamics during exercise in healthy volunteers. ${ }^{42}$ Based on these data, we developed a computational model of oxygen transport and metabolism in skeletal muscle that can simulate and predict muscle oxygen consumption dynamics during exercise. ${ }^{42}$ In this study, we integrated our model with a model of energy balance in myocytes ${ }^{41,62}$ to provide a more mechanistic expression for oxidative phosphorylation, ${ }^{35}$ which is linked to the ATPase and creatine kinase $(\mathrm{CK})$ reactions. ${ }^{62}$ With this model, muscle oxygen consumption dynamics at the cellular level can be estimated during exercise. Finally, model simulations are used to provide insight with respect to concentration and flux rate dynamics of key metabolites (PCr, ATP, ADP, $\mathrm{O}_{2}$ ) participating in oxidative phosphorylation and ATP homeostasis.

\section{METHODS}

\section{Model Development}

Oxygen utilization rate in skeletal muscle $\left(\mathrm{UO}_{2 \mathrm{~m}}\right)$ is linked to oxygen uptake rate in lungs $\left(\mathrm{VO}_{2 \mathrm{p}}\right)$ by transport processes within the tissues and via the cardiovascular system (Fig. 1). To analyze the dynamic relationship between $\mathrm{UO}_{2 \mathrm{~m}}$ and $\mathrm{VO}_{2 \mathrm{p}}$, a mathematical model is needed. In an earlier approach to developing this relationship, simulations were based on a model ${ }^{42}$ that approximated oxygen utilization in working skeletal muscle as a mono-exponential function of work rate. ${ }^{10}$ This model was used to analyze dynamic responses to exercise at several levels of intensity. ${ }^{42}$ With this simple model, however, distinct metabolic processes involved during exercise stimulus cannot be evaluated. Therefore, a more mechanistic model is needed that describes oxidative phosphorylation by incorporating ATPase and CK reactions. Such a

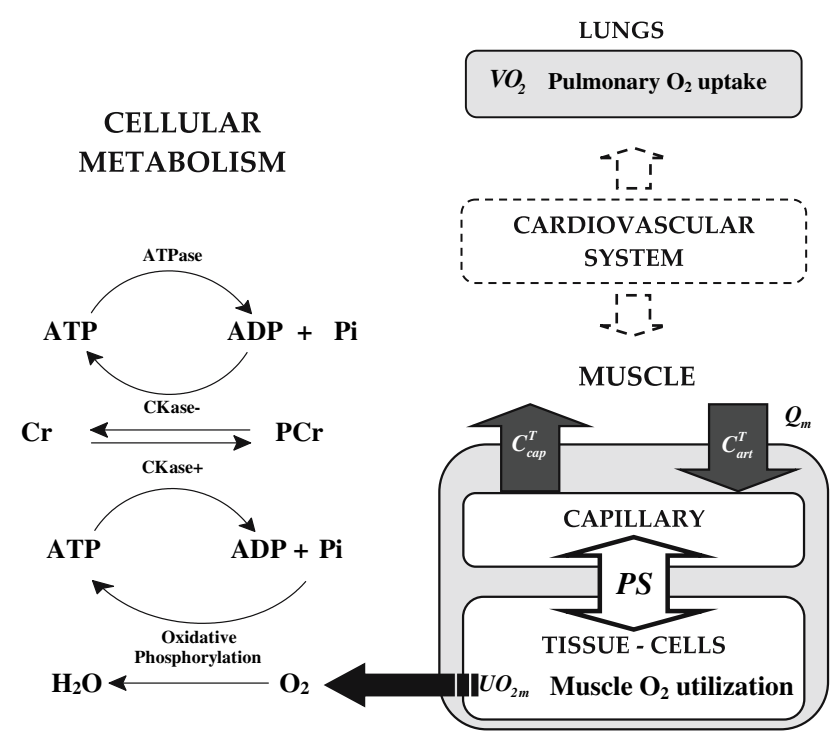

FIGURE 1. Oxygen utilization and transport between lungs and skeletal muscle and cellular metabolism during exercise. 
metabolic model has been developed previously. ${ }^{62}$ Here, this model of oxidative phosphorylation in myocytes is combined with a model of oxygen transport and utilization ${ }^{42}$ for analysis of responses to exercise.

\section{Mass Transport Balances}

Oxygen concentration dynamics in skeletal muscle are represented by compartmental mass balances. These balance equations involve total oxygen $\left(C_{\text {cap }}^{\mathrm{T}}\right.$, $\left.C_{\text {tis }}^{\mathrm{T}}\right)$ to free oxygen $\left(C_{\text {cap }}^{\mathrm{F}}, C_{\text {tis }}^{\mathrm{F}}\right)$ in the capillaries and tissues:

$$
V_{\text {cap }} \frac{d C_{\text {cap }}^{\mathrm{T}}}{d t}=Q_{\mathrm{m}}(t)\left(C_{\mathrm{art}}^{\mathrm{T}}-C_{\text {cap }}^{\mathrm{T}}\right)-\operatorname{PS}(t)\left(C_{\text {cap }}^{\mathrm{F}}-C_{\text {tis }}^{\mathrm{F}}\right)
$$

$$
V_{\text {tis }} \frac{d C_{\text {tis }}^{\mathrm{T}}}{d t}=\operatorname{PS}(t)\left(C_{\text {cap }}^{\mathrm{F}}-C_{\text {tis }}^{\mathrm{F}}\right)-\mathrm{UO}_{2 \mathrm{~m}}(t)
$$

Based on relationships between total, bound, and free oxygen concentrations, these equations have an equivalent representation with derivatives of free oxygen (Appendix I). The muscle blood flow, $Q_{\mathrm{m}}(t)$, the capillary-tissue transport coefficient represented as the permeability - surface area product, $\operatorname{PS}(t)$, and the oxygen utilization, $\mathrm{UO}_{2 \mathrm{~m}}(t)$, depend on exercise intensity. The rate of muscle oxygen uptake is defined as $\mathrm{VO}_{2 \mathrm{~m}}(t)=Q_{\mathrm{m}}(t)\left(C_{\mathrm{art}}^{\mathrm{T}}-C_{\text {cap }}^{\mathrm{T}}\right)$ (All variables and symbols are defined in the "List of Symbols").

\section{Metabolic Reaction Balances}

The metabolic reaction processes of oxidative phosphorylation during an exercise stimulus have been reported in Fig. 1 and can be expressed as the concentration dynamics of ATP and PCr:

$$
\begin{gathered}
\frac{d C_{\mathrm{ATP}}}{d t}=-\phi_{\mathrm{ATPase}}+\beta \phi_{\mathrm{OxPhos}}-\phi_{\mathrm{CK}}^{\mathrm{r}}+\phi_{\mathrm{CK}}^{\mathrm{f}} \\
\frac{d C_{\mathrm{PCr}}}{d t}=\phi_{\mathrm{CK}}^{\mathrm{r}}-\phi_{\mathrm{CK}}^{\mathrm{f}}
\end{gathered}
$$

where $\beta$ is the $\mathrm{P}: \mathrm{O}_{2}$ ratio in vivo and the reaction fluxes $\phi_{j}$ are functions of the ATP and $\mathrm{PCr}$ concentrations, which must satisfy the mass balances for conservation of adenosine and creatine:

$$
\begin{gathered}
C_{\mathrm{A}, \mathrm{tot}}=C_{\mathrm{ADP}}+C_{\mathrm{ATP}} \\
C_{\mathrm{Cr} \text {,tot }}=C_{\mathrm{Cr}}+C_{\mathrm{PCr}}
\end{gathered}
$$

The metabolic flux of oxygen is nonlinear related to the ADP and oxygen concentrations:

$$
\phi_{\mathrm{OxPhos}}=V_{\max }^{\mathrm{j}}\left(\frac{C_{\mathrm{ADP}}}{K_{\mathrm{ADP}}+C_{\mathrm{ADP}}}\right)\left(\frac{C_{\mathrm{tis}}^{\mathrm{F}}}{K_{\mathrm{m}}+C_{\mathrm{tis}}^{\mathrm{F}}}\right)
$$

where the rate coefficient, $V_{\max }^{j}$, depends on exercise intensity. The metabolic flux for the ATPase reaction is proportional to the ATP concentration:

$$
\phi_{\text {ATPase }}=k_{\mathrm{ATPase}}^{\mathrm{j}} C_{\mathrm{ATP}}
$$

where the reaction rate coefficient, $k_{\mathrm{ATPase}}^{\mathrm{j}}$, depends on exercise intensity. The forward and reverse reaction fluxes of $\mathrm{CK}$ are nonlinearly related to the coupled concentrations of $\mathrm{Cr}$, PCr, ADP, and ATP: $:^{62}$

$$
\begin{gathered}
\phi_{\mathrm{CK}}^{\mathrm{r}}=\frac{V_{\mathrm{CK}}^{\mathrm{r}}\left(\frac{C_{\mathrm{Cr}} C_{\mathrm{ATP}}}{K_{\mathrm{iq}}}\right)}{1+\frac{C_{\mathrm{ADP}}}{K_{\mathrm{ia}}}+\frac{C_{\mathrm{ATP}}}{K_{\mathrm{iq}}}+\frac{C_{\mathrm{PCC}}}{K_{\mathrm{ib}}}+\frac{C_{\mathrm{ADP}} C_{\mathrm{PCr}}}{K_{\mathrm{b}} K_{\mathrm{ia}}}+\frac{C_{\mathrm{Cr}} C_{\mathrm{ATP}}}{K_{\mathrm{iq}} K_{\mathrm{p}}}} \\
\phi_{\mathrm{CK}}^{\mathrm{f}}=\frac{V_{\mathrm{CK}}^{\mathrm{f}} \frac{C_{\mathrm{ADP}} C_{\mathrm{PCr}}}{K_{\mathrm{b}} K_{\mathrm{ia}}}}{1+\frac{C_{\mathrm{ADP}}}{K_{\mathrm{ia}}}+\frac{C_{\mathrm{ATP}}}{K_{\mathrm{iq}}}+\frac{C_{\mathrm{C}_{\mathrm{Cr}}}}{K_{\mathrm{ib}}}+\frac{C_{\mathrm{ADP}} C_{\mathrm{PCr}}}{K_{\mathrm{b}} K_{\mathrm{ia}}}+\frac{C_{\mathrm{Cr}} C_{\mathrm{ATP}}}{K_{\mathrm{iq}} K_{\mathrm{p}}}}
\end{gathered}
$$

The contributions of glycogenolysis and glycolysis to ATP synthesis are not included in the mathematical model Eq. (3) at this stage of model development. Thus, results obtained from simulations with this incomplete model need to be interpreted accordingly.

The reaction processes, Eqs. (3) and (4), are related to the transport processes, Eqs. (1) and (2), through the rates of oxygen metabolism, $\phi_{\text {OxPhos, }}$ and oxygen utilization:

$$
\phi_{\text {OxPhos }} V_{\mathrm{tis}}=\mathrm{UO}_{2 \mathrm{~m}}^{\mathrm{j}}
$$

which involves a tissue volume, $V_{\text {tis }}$, and depends on the exercise intensity $j$. The total muscle volume is defined as $V_{\mathrm{m}}=V_{\text {cap }}+V_{\text {tis }}$ where $V_{\mathrm{m}}$ is computed as a fraction of the whole body mass $(49 \%)$ and $V_{\text {cap }}, V_{\text {tis }}$ are each computed as a fraction of the $V_{\mathrm{m}} \cdot{ }^{42}$

\section{Exercise-dependent Functions}

In response to a step increase in work rate from a steady-state warm up condition, the dynamic response of blood flow $Q_{\mathrm{m}}^{\mathrm{j}}$ at exercise intensity $j$ is assumed to be exponential: ${ }^{42}$

$$
Q_{\mathrm{m}}^{\mathrm{j}}(t)=Q_{\mathrm{m}}^{\mathrm{W}}+\Delta Q_{\mathrm{m}}^{\mathrm{j}}\left[1-\exp \left(t^{\mathrm{W}}-t\right) / \tau_{Q_{\mathrm{m}}}^{\mathrm{j}}\right]
$$

where $Q_{\mathrm{m}}^{\mathrm{W}}$ is the steady-state value during warm-up, $\Delta Q_{\mathrm{m}}^{\mathrm{j}}$ is the increase in blood flow, and $\tau_{Q_{\mathrm{m}}}^{\mathrm{j}}$ is the time constants of muscle blood flow, and $t^{\mathrm{W}^{Q_{\mathrm{m}}}}$ is the initial time. In response to exercise, blood flow increases, which increases the rate of capillary-tissue transport: ${ }^{11}$

$$
\operatorname{PS}^{\mathrm{j}}(t)=\mathrm{PS}^{\mathrm{R}}+\Delta \mathrm{PS}\left[1-\exp \left(Q_{\mathrm{m}}^{\mathrm{R}}-Q_{\mathrm{m}}^{\mathrm{j}}\right) / Q_{\mathrm{C}}\right]
$$

where $\Delta \mathrm{PS}=\mathrm{PS}^{\mathrm{E}}-\mathrm{PS}^{\mathrm{R}}, \mathrm{PS}^{\mathrm{R}}$ and $Q_{\mathrm{C}}$ are constants. For a description of their meaning refer to the List of Symbol. 


\section{Model Simulation}

For comparison of simulated and experimental responses of oxygen obtained from human exercise experiments at several intensities, muscle oxygen saturation is computed: ${ }^{42}$

$$
\mathrm{StO}_{2 \mathrm{~m}}=\left[C_{\text {cap }}^{\mathrm{B}} V_{\text {cap }}+C_{\text {tis }}^{\mathrm{B}} V_{\text {tis }}\right] / T_{\mathrm{m}}
$$

The parameters $T_{\mathrm{m}}$ (total amount of $\mathrm{Hb}$ and $\mathrm{Mb}$ ), $V_{\text {cap }}$ and $V_{\text {tis }}$ are constants independent of exercise intensity. The initial conditions for the simulations of the dynamic responses are specified at a warm-up steady state (Appendix II):

$$
\begin{aligned}
& t=t^{\mathrm{W}}, \quad C_{\text {cap }}^{\mathrm{F}}=C_{\text {cap }}^{\mathrm{F}, \mathrm{W}}, \quad C_{\text {tis }}^{\mathrm{F}}=C_{\text {tis }}^{\mathrm{F}, \mathrm{W}}, \\
& C_{\mathrm{ATP}}=C_{\mathrm{ATP}}^{\mathrm{W}}, \quad C_{\mathrm{PCr}}=C_{\mathrm{PCr}}^{\mathrm{W}}
\end{aligned}
$$

To simulate responses to exercise, the model equations were solved numerically using a robust algorithm for stiff ordinary differential equations (DLSODE, http:// www.netlib.org/odepack/). ${ }^{31}$

\section{Parameter Estimation}

Values of most parameters in the model equations above have been determined previously and reported in Tables $1 \mathrm{~A}, \mathrm{~B}$ and $2 .^{42,62}$ Others are evaluated directly from steady-state relationships $\left(k_{\text {ATPase }}^{\mathrm{j}}, P S^{\mathrm{R}}\right)$ (Table 3$)$ or by optimal estimation $\left(\Delta Q_{\mathrm{m}}^{\mathrm{j}}, V_{\text {max }}^{\mathrm{j}}\right)(\mathrm{Ta}-$ ble 4).

From experiments, the values of $V_{\text {tis }}$ and $\mathrm{UO}_{2 \mathrm{~m}}^{\mathrm{j}}$ are determined so that at each exercise intensity we can evaluate $\phi_{\text {OxPhos }}$ from Eq. (11). Under steady-state conditions and assuming $\beta=6$ (32), Eqs. (3) and (4) simplify to

$$
0=-\phi_{\text {ATPase }}+6 \phi_{\text {OxPhos }}
$$

Combining this with Eq. (8) and given a constant value of $C_{\mathrm{ATP}}$, due to the ATP homeostasis, we can evaluate $k_{\text {ATPase }}^{\mathrm{j}}$ (see Table 3). To calculate $\mathrm{PS}^{\mathrm{R}}$, we consider Eqs. (1) and (2) at steady state under resting conditions:

$$
\begin{gathered}
0=Q_{\mathrm{m}}^{\mathrm{R}}\left(C_{\mathrm{art}}^{\mathrm{T}}-C_{\text {cap }}^{\mathrm{T}}\right)-\mathrm{PS}^{\mathrm{R}}\left(C_{\text {cap }}^{\mathrm{F}}-C_{\text {tis }}^{\mathrm{F}}\right) \\
0=\mathrm{PS}^{\mathrm{R}}\left(C_{\text {cap }}^{\mathrm{F}}-C_{\mathrm{tis}}^{\mathrm{F}}\right)-\mathrm{UO}_{2 \mathrm{~m}}^{\mathrm{R}}
\end{gathered}
$$

From experiments, $C_{\mathrm{art}}^{\mathrm{T}}, C_{\mathrm{tis}}^{\mathrm{F}, \mathrm{R}}, Q_{\mathrm{m}}^{\mathrm{j}}$ and $\mathrm{UO}_{2 \mathrm{~m}}^{\mathrm{R}}$ are determined. By simultaneous solution of Eqs. (17) and (18), incorporating the relationship $C_{\text {cap }}^{\mathrm{T}, \mathrm{R}}\left(C_{\text {cap }}^{\mathrm{F}, \mathrm{R}}\right)$, we estimate $\mathrm{PS}^{\mathrm{R}}$ and $C_{\text {cap }}^{\mathrm{F}, \mathrm{R}}$.

The parameters $\Delta Q_{\mathrm{m}}^{\mathrm{j}}$ and $V_{\max }^{\mathrm{j}}$ must be estimated for each subject at each exercise intensity. For this purpose, we find the parameter values that yield the best fit of the model output dynamics (from numerical solution of the model equations) to the experimental data. Specifically, for each subject at each exercise intensity, we minimize a least-squares objective function:

$$
\begin{aligned}
\Gamma\left(\Delta Q_{\mathrm{m}}^{\mathrm{j}}, V_{\text {max }}^{\mathrm{j}}\right)= & \frac{1}{2} \sum_{i=1}^{N}\left[\left(\frac{\mathrm{StO}_{2 \mathrm{~m}}\left(t_{i}\right)-\mathrm{StO}_{2 \mathrm{~m}}^{\mathrm{W}}}{\mathrm{StO}_{2 \mathrm{~m}}^{\mathrm{W}}}\right)_{\exp }\right. \\
& \left.-\left(\frac{\mathrm{StO}_{2 \mathrm{~m}}\left(t_{i}\right)-\mathrm{StO}_{2 \mathrm{~m}}^{\mathrm{W}}}{\mathrm{StO}_{2 \mathrm{~m}}^{\mathrm{W}}}\right)_{\text {mod }}\right]^{2}
\end{aligned}
$$

where $N$ is the number of data points. The objective function is minimized by numerical optimization using adaptive, non-linear algorithm (DN2FB, http:// www.netlib.org). ${ }^{19}$

\section{RESULTS}

In response to different exercise intensities, simulations represent dynamic responses of muscle ATP and $\mathrm{PCr}$ concentrations, oxygen saturation, $\mathrm{StO}_{2 \mathrm{~m}}$, ATPase $\left(\phi_{\text {ATPase }}\right)$, oxidative phosphorylation $\left(\phi_{\text {OxPhos }}\right)$, and net $\mathrm{CK}\left(\phi_{\mathrm{CK}}^{\mathrm{r}}-\phi_{\mathrm{CK}}^{\mathrm{f}}\right)$ flux rates. By fitting of simulated $\mathrm{StO}_{2 \mathrm{~m}}$ to experimental data, optimal estimates were obtained for the maximal flux rate of oxidative phosphorylation $V_{\max }^{\mathrm{j}}$ and change in muscle

TABLE 1. (A) Values of muscle oxygen utilization, $\mathrm{UO}_{2 \mathrm{~m}}^{j}$, and pulmonary oxygen uptake, $\mathrm{VO}_{2 \mathrm{p}}^{\mathrm{j}},\left(\mathrm{mmol}_{\mathrm{min}}^{-1}\right)$ at various exercise intensities $(j=R, W, M, H, V)^{42}$ and $(B)$ Values of blood flow $Q_{m}\left(L \min ^{-1}\right)$ at various exercise intensities $(j=R, W)$, mean response times $\tau_{Q_{-} m}(\mathbf{s})(\mathrm{j}=\mathrm{M}, \mathrm{H}, \mathrm{V})$ and compartment volumes $V(\mathrm{~L})$ for model simulations.

Panel $A$

Muscle oxygen utilization $\mathrm{UO}_{2 \mathrm{~m}}^{\mathrm{j}}$

Parameter

Mean \pm SD $\quad 2 \pm 0.2$

Pulmonary oxygen uptake $\mathrm{VO}_{2 \mathrm{p}}^{\mathrm{j}}$

Parameter $\quad \mathrm{VO}_{2 \mathrm{p}}^{\mathrm{R}}$

Mean \pm SD $\quad 9.8 \pm 0.9$

Panel B

Parameter

$9.8 \pm 0.9 \quad 23.6 \pm 3.5$

$\mathrm{UO}_{2 \mathrm{~m}}^{\mathrm{W}}$

$15 \pm 4$

$\mathrm{VO}_{2 \mathrm{p}}^{\mathrm{W}}$

Mean \pm SD

$Q_{\mathrm{m}}^{\mathrm{R}}$

$Q_{m}^{R}$
$0.8 \pm 0.1$

$\begin{array}{ccc}\mathrm{UO}_{2 m}^{\mathrm{M}} & \mathrm{UO}_{2 m}^{\mathrm{H}} & \mathrm{UO}_{2 m}^{\mathrm{V}} \\ 58 \pm 18 & 83 \pm 18 & 109 \pm 13 \\ \mathrm{VO}_{2 p}^{\mathrm{M}} & \mathrm{VO}_{2 p}^{\mathrm{H}} & \mathrm{VO}_{2 p}^{\mathrm{V}} \\ 70.7 \pm 17 & 96 \pm 15 & 122 \pm 11.6 \\ \tau_{Q_{m}}^{\mathrm{M}} & \tau_{Q_{m}}^{H} & \tau_{Q_{m}}^{\mathrm{V}} \\ 21.3 \pm 2 & 24 \pm 1 & 24 \pm 1\end{array}$

$V_{\text {cap }}$

$2.3 \pm 0.3$
$V_{\text {tis }}$

$31 \pm 5$ 
TABLE 2. Model parameters values for simulation of all experiments. ${ }^{42,62}$

\begin{tabular}{|c|c|c|c|c|c|}
\hline \multicolumn{3}{|c|}{ Transport model } & \multicolumn{3}{|c|}{ Metabolic model } \\
\hline Notation & Unit & Value & Notation & Unit & Value \\
\hline$K_{\mathrm{Hb}}$ & $(\mathrm{mM})^{-2.7}$ & 7800.7 & $C_{\mathrm{Cr}, \text { tot }}$ & $(\mathrm{mM})$ & 42 \\
\hline$K_{\mathrm{Mb}}$ & $(\mathrm{mM})^{-1}$ & 308.6 & $C_{\text {ATP }}^{R}$ & $(\mathrm{mM})$ & 8.2 \\
\hline$C_{\text {art }}^{F}$ & $(\mathrm{mM})$ & 0.135 & $V_{\mathrm{CK}}$ & $\left(\mathrm{mM} \min ^{-1}\right)$ & 3008.6 \\
\hline$C_{\text {tis }}^{F, R}$ & $(\mathrm{mM})$ & $3.375 \times 10^{-2} 30$ & $V_{\mathrm{CK}}^{N}$ & $\left(\mathrm{mM} \mathrm{min}{ }^{-1}\right)$ & 6000 \\
\hline$C_{\mathrm{rbc}, \mathrm{Hb}}$ & $(\mathrm{mM})$ & 5.18 & $K_{\mathrm{b}}$ & $(\mathrm{mM})$ & 1.11 \\
\hline$C_{\mathrm{mc}, \mathrm{Mb}}$ & $(\mathrm{mM})$ & 0.5 & $K_{\mathrm{p}}$ & $(\mathrm{mM})$ & 3.8 \\
\hline $\mathrm{Hct}$ & $(-)$ & 0.45 & $K_{\text {ia }}$ & $(\mathrm{mM})$ & 0.135 \\
\hline$Q_{C}$ & $\left(\mathrm{~L} \min ^{-1}\right)$ & $8^{\mathrm{a}}$ & $K_{\mathrm{ib}}$ & $(\mathrm{mM})$ & 3.9 \\
\hline$V_{\text {cap }}$ & $(\mathrm{L})$ & $7 \% V_{\mathrm{m}}$ & $K_{\mathrm{iq}}$ & $(\mathrm{mM})$ & 3.5 \\
\hline$V_{\text {tis }}$ & (L) & $93 \% V_{\mathrm{m}}$ & $K_{\mathrm{ADP}}$ & $(\mathrm{mM})$ & 0.058 \\
\hline$W_{m c}$ & $(-)$ & 0.75 & $K_{\mathrm{m}}$ & $(\mathrm{mM})$ & $7 \times 10^{-417}$ \\
\hline$P S^{E}$ & $\left(\mathrm{~L} \min ^{-1}\right)$ & 20,000 & & & \\
\hline
\end{tabular}

a This work.

TABLE 3. Means $(n=7)$ of reaction rate coefficients for ATPase $k_{A T P a s e}^{j}\left(\min ^{-1}\right)$ at different exercise intensities $(j=R, W, M, H, V)$ and of permeability-surface area at rest $\left(L \min ^{-1}\right)$.

\begin{tabular}{lcccccc}
\hline Parameter & $k_{\text {ATPase }}^{\mathrm{R}}$ & $k_{\text {ATPase }}^{W}$ & $k_{\text {ATPase }}^{M}$ & $k_{\text {ATPase }}^{\mathrm{H}}$ & $k_{\text {ATPase }}^{\mathrm{V}}$ & PS $^{\mathrm{R}}$ \\
\hline Mean \pm SD & $0.048 \pm 0.008$ & $0.36 \pm 0.04$ & $1.4 \pm 0.3$ & $2 \pm 0.3$ & $2.6 \pm 0.4$ & $113 \pm 26$
\end{tabular}

TABLE 4. Mean $(n=7)$ parameter values for exercise intensity $j=M, H, V$ : change in muscle blood flow $\Delta Q_{m}^{j}\left(L\right.$ min $\left.^{-1}\right)$ from warmup; maximal rate of oxidative phosphorylation $V_{\max }\left(\mathrm{mM} \mathrm{min}^{-1}\right)$.

\begin{tabular}{lcccccc}
\hline Parameter & $\Delta Q_{m}^{M}$ & $\Delta Q_{m}^{H}$ & $\Delta Q_{m}^{V}$ & $V_{\max }^{M}$ & $V_{\max }^{H}$ & $V_{\max }^{\nu}$ \\
\hline Mean \pm SD & $5.6 \pm 2.2$ & $7.6 \pm 2$ & $9.7 \pm 2$ & $45 \pm 15$ & $45 \pm 15$ & $44 \pm 16$ \\
\hline
\end{tabular}

blood flow $\Delta Q_{\mathrm{m}}^{\mathrm{j}}$ of seven subjects at exercise intensities $\mathrm{j}=\mathrm{M}, \mathrm{H}, \mathrm{V}$. From model simulations, mean response times $\left(\tau_{\mathrm{VO}_{2 \mathrm{~m}}}, \tau_{\mathrm{UO}_{2 \mathrm{~m}}}, \tau_{\mathrm{PCr}}\right)$ were computed for muscle $\mathrm{O}_{2}$ uptake, muscle $\mathrm{O}_{2}$ utilization, and $\mathrm{PCr}$, respectively.

Typical $\mathrm{StO}_{2 \mathrm{~m}}$ step responses to a change in exercise intensity relative to a warm-up steady state, $\mathrm{StO}_{2 \mathrm{~m}}^{\mathrm{W}}$, for one subject are presented in Fig. 2. The decrease in $\mathrm{StO}_{2 \mathrm{~m}}$ is greater for a higher exercise intensity. Referring to the same subject, model simulations of $\mathrm{UO}_{2 \mathrm{~m}}^{\mathrm{j}}$ responses to increased exercise intensities $(\mathrm{j}=\mathrm{M}, \mathrm{H}, \mathrm{V})$ are compared to measured $\mathrm{VO}_{2 \mathrm{p}}^{\mathrm{j}}$ (Fig. 3). Dynamic responses of $\mathrm{UO}_{2 \mathrm{~m}}^{\mathrm{j}}$ are faster than the dynamic responses of $\mathrm{VO}_{2 \mathrm{~m}}^{\mathrm{j}}$ for all subjects. The corresponding mean response times are compared in Table 5.

From optimal estimation of $V_{\max }^{j}$ from seven subjects, their mean values are independent of exercise intensity (Table 4). In contrast, the mean change in muscle blood flow $\Delta Q_{\mathrm{m}}^{\mathrm{j}}$ increased by about $80 \%$ with higher exercise intensity.

Model simulated metabolic flux rates $\phi_{\text {OxPhos }}$ and $\phi_{\mathrm{CK}}^{\mathrm{r}}-\phi_{\mathrm{CK}}^{\mathrm{f}}$ in response to a step change in $\phi_{\mathrm{ATPase}}$ (Table 3), corresponding to a given exercise intensity, are presented in Fig. 4. As expected (Eq. 3), at all exercise intensities, $6 \phi_{\text {OxPhos }}$ reaches the same steady as $\phi$ ATPase. Accordingly to the direct proportionality of $\phi_{\text {OxPhos }}$ and $\mathrm{UO}_{2 \mathrm{~m}}^{\mathrm{j}}$ (Eq. 11), the mean response time of

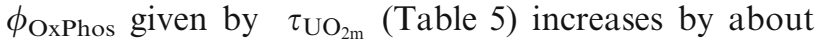

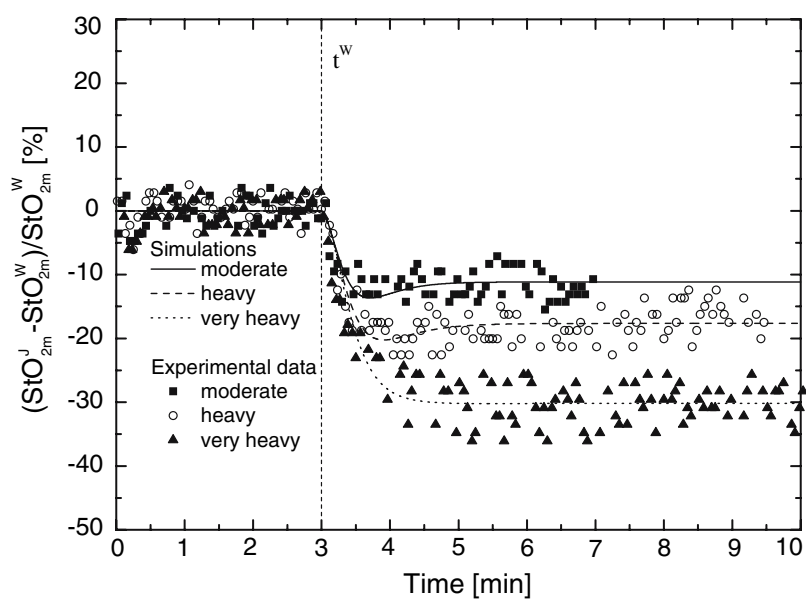

FIGURE 2. Relative oxygen saturation in muscle, $\mathrm{StO}_{2 \mathrm{~m}}^{\mathrm{j}}$ : for representative subject responses to step changes from a warm-up steady-state condition (W) to a steady state during moderate, heavy, and very heavy exercise $(j=M, H, V)$. Model output compared with experimental data. ${ }^{42}$ 

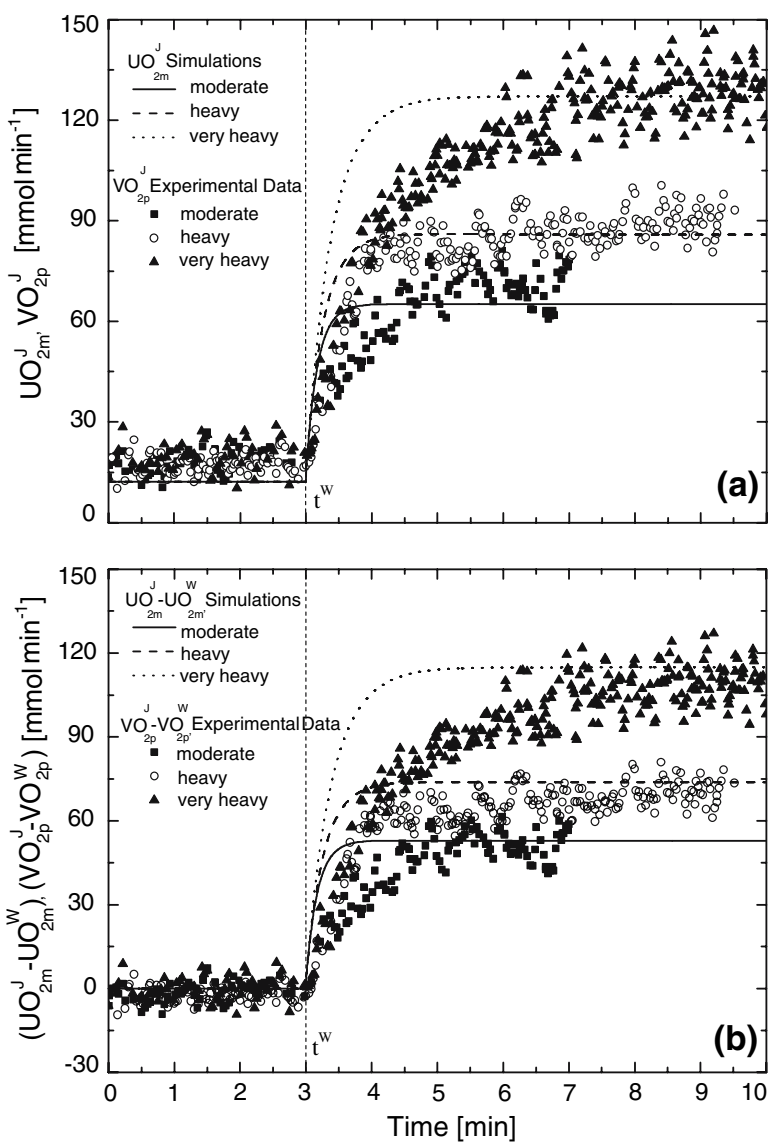

FIGURE 3. Comparison between dynamic responses of experimental pulmonary oxygen uptake and simulated muscle oxygen consumption for a representative subject. ${ }^{42}$ Forcing functions are step changes from a warm-up steady-state condition (W) to a work rate of moderate, heavy, and very heavy intensity exercise $(\mathrm{j}=\mathrm{M}, \mathrm{H}, \mathrm{V})$. Muscle oxygen consumption and pulmonary oxygen uptake are represented (a) in absolute terms as $\mathrm{VO}_{2 \mathrm{p}}$ and $\mathrm{UO}_{2 \mathrm{~m}}$, respectively and (b) as absolute changes from warm-up steady-state values, i.e., $\mathrm{VO}_{2 p}^{\mathrm{j}}-\mathrm{VO}_{2 \mathrm{p}}^{\mathrm{W}}$ and $\mathrm{UO}_{2 \mathrm{~m}}^{\mathrm{j}}-\mathrm{UO}_{2 \mathrm{~m}}^{\mathrm{W}}$, respectively.

$35 \%$ from moderate to very high intensity exercise. While $\phi_{\text {OxPhos }}$ increases monotonically to the steady state, $\phi_{\mathrm{CK}}^{\mathrm{r}}-\phi_{\mathrm{CK}}^{\mathrm{f}}$ shows an initial step decrease and then increases in exponential manner towards zero. The dynamic responses of the $\phi_{\mathrm{CK}}^{\mathrm{r}}-\phi_{\mathrm{CK}}^{\mathrm{f}}$ and $\phi_{\mathrm{OxPhos}}$ fluxes are closely balanced to guarantee ATP homeostasis.

The $C_{\text {ADP }}$ at steady-state, during exercise at all intensities, reached in our simulations (i.e., Figs. 2-5),

TABLE 5. Mean $(N=7)$ response times for exercise intensity $\mathrm{j}=\mathrm{M}, \mathrm{H}, \mathrm{V}$ of muscle oxygen uptake $\tau_{\mathrm{vo}_{2 m}}(\mathbf{s})$, muscle oxygen utilization $\tau_{\mathrm{UO}_{2 \mathrm{~m}}}^{\mathrm{j}}$ (s) and PCr dynamics $\tau$ pcr (s).

\begin{tabular}{cccclc}
\hline \multicolumn{2}{c}{ Mean \pm SD } & \multicolumn{2}{c}{ Mean \pm SD } & \multicolumn{2}{c}{ Mean \pm SD } \\
\hline$\tau_{\mathrm{VO}_{2 m}}^{\mathrm{M}}$ & $18 \pm 3$ & $\tau_{\mathrm{VO}_{2 m}}^{\mathrm{H}}$ & $18 \pm 2$ & $\tau_{\mathrm{VO}_{2 m}}^{\mathrm{V}}$ & $20 \pm 3$ \\
$\tau_{\mathrm{MO}_{2 m}}^{\mathrm{V}}$ & $14 \pm 3$ & $\tau_{\mathrm{UO}_{2 m}}^{\mathrm{H}}$ & $15 \pm 4$ & $\tau_{\mathrm{VO}_{2 m}}^{\mathrm{V}}$ & $18 \pm 4$ \\
$\tau_{\mathrm{PCr}}^{\mathrm{M}}$ & $14 \pm 3$ & $\tau_{\mathrm{PCr}}^{\mathrm{H}}$ & $15 \pm 4$ & $\tau_{\mathrm{PCr}}^{\mathrm{V}}$ & $18 \pm 4$ \\
\hline
\end{tabular}

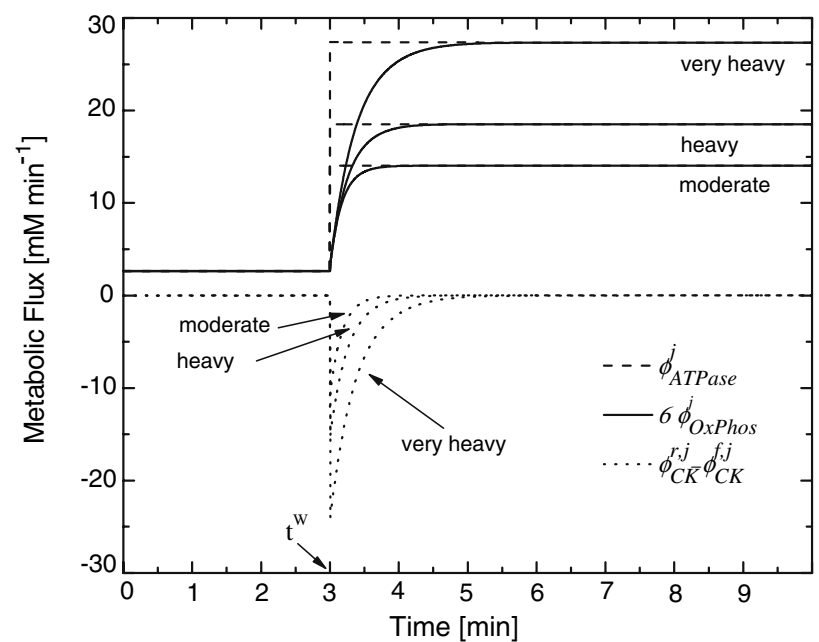

FIGURE 4. Simulation results for representative subject

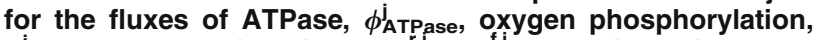
$\phi_{\mathrm{OxPhos}}^{\mathrm{j}}$ and creatine kinase, $\phi_{\mathrm{CK}}^{\mathrm{r}, \mathrm{j}}-\phi_{\mathrm{CK}}^{\mathrm{fj}, \mathrm{j}}$. The simulations represent the dynamic between the warm-up steady state and the three levels of exercise intensity: moderate, heavy, and very heavy $(\mathrm{j}=\mathrm{M}, \mathrm{H}, \mathrm{V})$.

consistently increases from moderate to very heavy intensity of exercise $\left(\mathrm{M}, 2.32 \cdot 10^{-3} \mathrm{mM} ; \mathrm{H}\right.$, $\left.5.26 \cdot 10^{-3} \mathrm{mM} ; \mathrm{V}, 1.45 \cdot 10^{-2} \mathrm{mM}\right)$.

The ATP concentration change is small compare to the $\mathrm{PCr}$ concentration change which decreases in response to a change in exercise intensity (Fig. 5). The mean response time of $\mathrm{PCr}, \tau_{\mathrm{PCr}}$, shows a change with exercise that is similar to the change of $\tau_{\mathrm{UO}_{2 \mathrm{~m}}}$. Model simulations were also performed assuming that the Michaelis-Menten parameter $K_{\mathrm{m}}$ is sufficiently small in

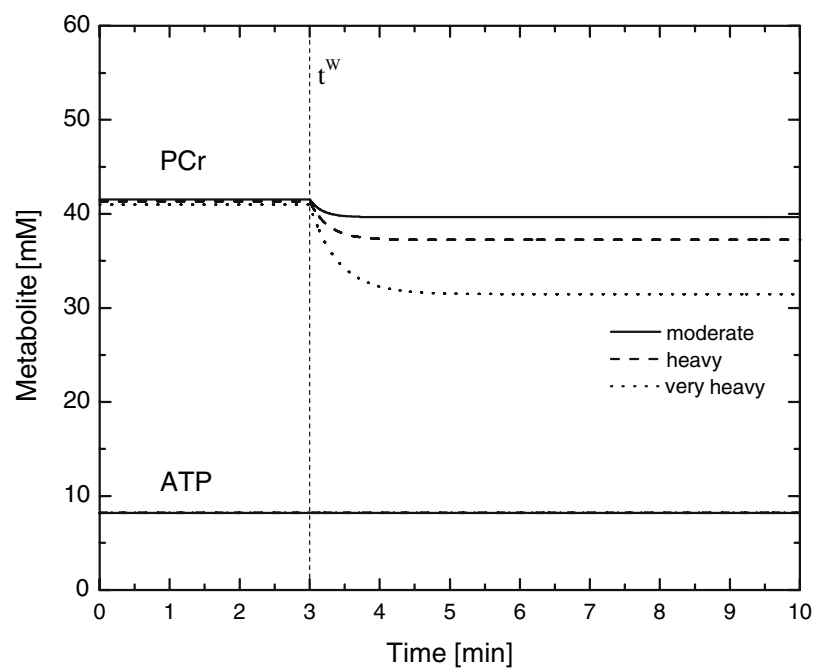

FIGURE 5. Simulation results for representative subject. Comparison of absolute variation between the $\mathrm{PCr}$ breakdown and the ATP consumption. The simulations are carried out starting from the warm-up steady state to the three levels of exercise intensity: moderate (continuous), heavy (dashed) and very heavy (dotted). 
Eq. (7) such that $\phi_{\text {OxPhos }}$ is independent of oxygen concentration. In response to exercise, the mean response times for $\mathrm{UO}_{2 \mathrm{~m}}^{\mathrm{j}}$ and $C_{\mathrm{PCr}}\left(\tau_{\mathrm{UO}_{2 \mathrm{~m}}}, \tau_{\mathrm{PCr}}\right)$ are nearly the same for moderate, heavy and very heavy exercise $(13,13,15 \mathrm{~s})$. These response times are about 2-3 s less than those for which $\phi_{\text {OxPhos }}$ depends on oxygen concentration (Table 5). Also, for $\phi_{\text {OxPhos }}$ with no oxygen dependence, the mean values of $V_{\max }^{j}(44$ (M), $43(\mathrm{H}), 37$ (V) $\mathrm{mM} \mathrm{min}{ }^{-1}$ ) compared to those given in Table 4 differ only for the very heavy intensity $(\mathrm{j}=\mathrm{V})$. Although $V_{\max }^{\mathrm{V}}$ decreased from 44 to $37 \mathrm{mM}$ $\min ^{-1}$ without oxygen dependence, the mean response time of muscle oxygen uptake $\tau_{\mathrm{VO}_{2 m}}$ did not change.

A reduction of the muscle volume, $V_{\mathrm{m}}$, from 40 to 91 leads to greater amplitude changes of $\phi_{\text {ATPase }}$, net $\phi_{\mathrm{CK}}^{\mathrm{r}}-\phi_{\mathrm{CK}}^{\mathrm{f}}$ fluxes, $C_{\mathrm{PCr}}$ and about a $50 \%$ increase in $\tau_{\mathrm{PCr}}$ and $\tau_{\mathrm{UO}_{2 \mathrm{~m}}}$. Also, the estimated $V_{\max }^{\mathrm{j}}$ in this range lies between 45 and $25 \mathrm{mM} \mathrm{min}^{-1}$ and was independent of exercise intensity.

\section{DISCUSSION}

A mathematical model based on mass balances and metabolic and transport fluxes was successfully developed and applied to study the interacting regulation of cellular respiration and bioenergetics required to maintain ATP homeostasis during step transitions from rest to work rate intensities representing moderate, heavy, and very heavy exercise on a cycle ergometer in humans. This model couples oxygen transport and utilization in skeletal muscle ${ }^{42}$ to a model of cellular metabolism and energetics. ${ }^{62}$ The latter model, which describes oxidative phosphorylation, ATPase and $\mathrm{CK}$ reactions in finger and wrist flexors during an imposed stimulus, was adapted to investigate cellular energetics in large muscle groups.

In this study, transport and metabolic processes at the onset of exercise were quantified in the steady state and during the exercise transition by comparing model simulations with measurements of pulmonary oxygen uptake and muscle oxygen saturation at different exercise intensities on a cycle ergometer. Then, the dynamics of the metabolic flux rates of $\phi_{\text {OxPhos }}, \phi_{\text {AT }-}$ Pase, ${ }_{\mathrm{C}}^{\mathrm{f}} \mathrm{CK}$ and $\phi_{\mathrm{CK}}^{\mathrm{r}}$ were simulated for each of the seven subjects at three levels of exercise intensity.

\section{Internal and External Respiration}

The regulation of cellular oxygen consumption in skeletal muscle during exercise in vivo depends on electron flow, proton pumping, metabolic fluxes of NADH, ADP-dependent feedback control and oxygen delivery. ${ }^{16}$ At the cellular level, the dynamics of oxidative phosphorylation to a step increase in energy demand is expected to be fast $(<450 \mathrm{~ms})$ based on studies with isolated mitochondria in vitro. ${ }^{12,58}$ This response time is at least two orders of magnitude faster than in vivo measurements ${ }^{64,65}$ of oxygen uptake dynamics at the mouth ( $45 \mathrm{~s})$. Since direct in vivo measurements of muscle oxygen consumption dynamics $\left(\mathrm{UO}_{2 \mathrm{~m}}\right)$ are difficult to obtain in humans during exercise, an indirect estimate is obtained from pulmonary oxygen uptake $\left(\mathrm{VO}_{2 \mathrm{p}}\right)$ based on measurable variables at the airway opening. ${ }^{66}$ Under nonsteady state conditions, however, $\mathrm{VO}_{2 \mathrm{p}}$ cannot provide a reliable estimate of muscle oxygen consumption because of differences in dynamics at exercise onset. ${ }^{37}$ Experimentally, Grassi et al. ${ }^{29}$ found no significant differences in response dynamics between muscle and pulmonary uptake, $\mathrm{VO}_{2 \mathrm{~m}}$ and $\mathrm{VO}_{2 \mathrm{p}}$, during the transition from light to moderate intensity exercise. The methodology used for measuring $\mathrm{VO}_{2 \mathrm{~m}}$ dynamics across the femoral bed during exercise may not be sufficiently accurate because the $\mathrm{VO}_{2 \mathrm{~m}}$ response depends on lumped measurements of oxygen content in the femoral vein and bulk measurements of femoral blood flow, ${ }^{61}$ which may result in having slow muscle oxygen uptake dynamics close to that of pulmonary oxygen uptake. Several studies have considered whether the observed dynamics of oxygen uptake at the onset of exercise is the manifestation of an "inertia" in the rate of $\mathrm{O}_{2}$ delivery to the muscle fibers ${ }^{18}$ or of an intrinsic slowness of the intracellular oxidative metabolism. ${ }^{23,28}$

\section{Linking Simulated and Measured Fluxes}

The model developed here takes into account the dynamic interplay of oxygen delivery (via convection and diffusion), ${ }^{42}$ and mechanisms of cellular energy metabolism occurring in skeletal muscle during exercise. $^{62}$ Specifically, muscle oxygen saturation (Fig. 2) and pulmonary oxygen uptake (Fig. 3) measurements were linked using a mathematical model to quantify the metabolic fluxes involved in cellular respiration in skeletal muscle during rhythmic voluntary contractions on a cycle ergometer.

According to the model of cellular energy metabolism proposed by Vicini and Kushmerick ${ }^{62} \phi_{\text {OxPhos }}$ is coupled to the metabolic fluxes of $\phi_{\mathrm{CK}}^{\mathrm{r}}$ and $\phi_{\mathrm{CK}}^{\mathrm{f}}$ (Fig. 4). This model describes how the dynamics of net PCr breakdown $\left(\phi_{\mathrm{CK}}^{\mathrm{r}}-\phi_{\mathrm{CK}}^{\mathrm{f}}\right)$ results in a drop of $C_{\mathrm{PCr}}$ to supply the amount of ATP (Fig. 5) that $\phi_{\text {OxPhos }}$ cannot synthesize rapidly enough (Fig. 4) to maintain ATP homeostasis at exercise onset (Fig. 5). Similarly, to Vicini and Kushmerick, ${ }^{62}$ we described cellular energy balance in skeletal muscle without including the glycolytic pathway as a source of ATP synthesis. Under certain conditions, such as maximal or supramaximal 
exercise, as well as at the onset of high intensity exercise, the glycolytic contribution to ATP synthesis may be significant. The results of our simulation at the onset of heavy and very heavy intensity exercise would most likely be different, were the glycolytic contribution be taken into account. Specifically, we speculate that the rate of phosphocreatine breakdown would be reduced in proportion to the net rate of lactate formation from glycolysis throughout the exercise period.

The simulated dynamic response of muscle oxygen utilization (indicated by $\left.\phi_{\text {OxPhos }}\right)$ was always significantly faster than the response of pulmonary oxygen uptake at all intensities (Fig. 3).

The dynamic response $\tau_{\mathrm{UO}_{2 \mathrm{~m}}}$ of simulated $\mathrm{UO}_{2 \mathrm{~m}}$ or

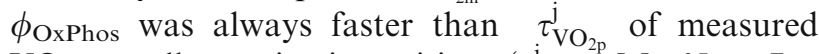
$\mathrm{VO}_{2 \mathrm{p}}$ at all exercise intensities $\left(\tau_{\mathrm{VO}_{2 \mathrm{p}}}^{\mathrm{j}}, \mathrm{M}: 65 \pm 7 \mathrm{~s}\right.$; $100 \pm 24 \mathrm{~s} ; 82 \pm 31 \mathrm{~s}) .{ }^{42}$ Furthermore, $\tau_{\mathrm{UO}_{2 \mathrm{~m}}}$ based on model simulation in which $\phi_{\text {OxPhos }}$ depends on oxygen concentration Eq. (7) was 2-3 s larger than $\tau_{\mathrm{UO}_{2 m}}$ obtained using an empirically derived exponential function for $\mathrm{UO}_{2 \mathrm{~m}} \cdot{ }^{42}$ This difference vanished when $\phi_{\text {OxPhos }}$ did not include oxygen dependence. The dependence of $\phi_{\text {OxPhos }}$ on oxygen concentration may become evident at low oxygen concentration values, especially at high-intensity exercise.

It should be noted that without the oxygen dependence, the mean $V_{\max }^{\mathrm{V}}$ estimated is reduced from 44 to $37 \mathrm{mmol} \mathrm{l}^{-1} \mathrm{~min}^{-1}$. Therefore, the original expression for $\phi_{\text {OxPhos }}$ proposed by Vicini and Kushmerick ${ }^{62}$ was modified in the present model by including an oxygen dependency, which is important at higher exercise intensities where oxygen could be very low and affect metabolism. ${ }^{67-69}$ During exercise, oxygen dependency affects the dynamics of muscle oxygen utilization, but does not affect muscle oxygen uptake $\tau_{\mathrm{VO}_{2 \mathrm{~m}}}^{\mathrm{j}}$ because the venous oxygen concentration dynamics is not greatly affected. It is worth noticing that, in our model, we assume the rate of ATP production associated with oxidative phosphorylation to be six times the rate of oxygen consumption (i.e., $\beta=6$ ). Although the $\mathrm{P} / \mathrm{O}_{2}$ ratio may be 5 or 6 , as proposed in some authors, ${ }^{45,56}$ a recent review suggests values between 3 and $6 .{ }^{32} \mathrm{Nev}-$ ertheless, when different values of $\beta$ were used in the simulations, the estimated dynamics of oxidative phosphorylation remain the same at all exercise intensities, even though it affected the value of $k_{\mathrm{ATPase}}^{\mathrm{j}}$ and the estimation of $V_{\max }^{j}$.

The kinetic parameters of cellular metabolism Eq. (9-10) were previously estimated for nerve stimulation of finger and wrist flexors. ${ }^{62}$ The same parameter values were used in this study even though muscles engaged in bicycle exercise were voluntarily activated. Nevertheless, model simulations of the dynamics of oxidative phosphorylation and $\mathrm{PCr}$, characterized by the mean response times $\tau_{\mathrm{UO}_{2 \mathrm{~m}}}$ and $\tau_{\mathrm{PCr}}$, are in agreement with previously published studies performed in human subjects under similar conditions. ${ }^{53}$

The model equations account for cellular ATPase, oxidative phosphorylation and CK fluxes variations in skeletal muscle during exercise, where the cellular respiration is regulated by feedback control with dependence from ADP and oxygen concentrations. ${ }^{13-15,67-69}$ It is worth to note that, in the literature, several feedback and feed forward control models have been proposed to describe the regulation of cellular respiration in vivo, such as (1) feedback control using a Michaelis-Menten relationship between oxidative phosphorylation and [ADP], (2) higher-order feedback control using an expression in which the Hill coefficient is greater than 1, or (3) a more fundamental expression of relating oxidative phosphorylation to the free energy of ATP hydrolysis. ${ }^{34,41,63}$ Furthermore, some other scientists have proposed feed forward mechanisms to control oxidative phosphorylation. ${ }^{2,40}$ However, the experimental data available in the present study are not sufficient to address this issue; therefore, we adopted the approach successfully applied previously to in vivo data obtained by NMR spectroscopy. ${ }^{62}$

The computation of $C_{\mathrm{ADP}}$ at steady-state during constant work rate exercise (M: $2.74 \cdot 10^{-3} \mathrm{mM}$; H: $\left.5.94 \cdot 10^{-3} \mathrm{mM} ; \mathrm{V}: 1.54 \cdot 10^{-2} \mathrm{mM}\right)$, based on the equilibrium assumption using the $\mathrm{CK}$ equilibrium constant $K_{\text {eq }}=177 \quad\left(\mathrm{pH}=7, \quad T=38^{\circ} \mathrm{C}\right)^{57}$ and $C_{\mathrm{ATP}}, C_{\mathrm{PCr}}, C_{\mathrm{Cr}}$ obtained from simulations using full kinetic expressions for CK (Eqs. 9-10), is consistent with the $C_{\mathrm{ADP}}$ values simulated $\left(\mathrm{M}: 2.32 \cdot 10^{-3} \mathrm{mM}\right.$; $\mathrm{H}: 5.26 \cdot 10^{-3} \mathrm{mM}$; V: $\left.1.45 \cdot 10^{-2} \mathrm{mM}\right)$. Moreover, our approach allows for dynamic information on the metabolic fluxes, which is useful to investigate the mechanisms regulating the dynamics of oxidative phosphorylation during exercise.

\section{Model Transport Parameter}

In this model, mass transport of oxygen between capillary blood and tissue depends on permeabilitysurface area coefficient PS, which varies with muscle blood flow (Eq. 13) that in turn depends on exercise intensity. ${ }^{11}$ The dependency of $P S$ on $Q_{\mathrm{m}}^{\mathrm{j}}$ allows the model to simulate resting and exercise conditions. Although the expression used to describe the variation of PS with work rate is phenomenological, it is consistent with tissue oxygen concentration values at rest and in agreement with the hypothesis of a capillary recruitment during exercise. ${ }^{33}$ Regardless whether there is capillary recruitment during exercise or just an increase in blood flow rate through the already recruited capillaries, in our simulations, PS coefficient must be set to a sufficiently high value to ensure enough oxygen supply 
to contracting muscle fibers to match the energy demand at all intensities. ${ }^{42}$ The parameter $Q_{\mathrm{C}}$ that affects the PS $-Q_{\mathrm{m}}^{\mathrm{j}}$ relationship (Eq. 13), must be sufficiently small so that simulations of arterio-venous oxygen differences are consistent with the blood flow increase with exercise intensity. Also, from Eq. (12), the blood flow increases between steady states, $\Delta Q_{\mathrm{m}}^{\mathrm{j}}$ were in agreement with those found previously at all intensities. ${ }^{42}$

\section{Limitations of Experimental Data}

Model simulations indicate that a reduction of the amount of active muscle, $V_{\mathrm{m}}$, from 40 to 91 and thus a reduction of capillary and tissue volume $\left(V_{\text {cap }}, V_{\text {tis }}\right)$ engaged during exercise, affects the temporal profile of the metabolites, the maximum rate of oxidative phosphorylation $V_{\max }^{\mathrm{j}}$ and the mean response time of cellular oxygen utilization $\tau_{\mathrm{UO}_{2 \mathrm{~m}}}^{\mathrm{j}}$. In particular, the smaller the $V_{\mathrm{m}}$ values are the faster the dynamics of oxygen concentration in capillary blood and in tissue appears, for a fixed value of $V_{\max }^{j}$. The $V_{\max }^{\mathrm{j}}$ value estimated by Vicini and Kushmerick ${ }^{62}\left(30 \mathrm{mM} \mathrm{min}{ }^{-1}\right)$ falls in the range of values determined in our simulations (45$25 \mathrm{mM} \mathrm{min}{ }^{-1}$ ) when varying $V_{\mathrm{m}}$ between 40 and 91 . The estimation of the $V_{\max }^{\mathrm{j}}$ parameter is limited by the experimental uncertainty in determining active muscle volume and the microvascular volume distribution during exercise. In the present study, the volume of muscle recruited by each subject during exercise was assumed to be a percentage of the whole body volume; thus, a more accurate determination of the functional relationship between active muscle volume engaged and work rate is needed. Experimental measurements of key metabolites, such as PCr in large muscle groups, could be coupled to the model developed to estimate the active muscle volume unknown. Future model development will take into consideration motor unit recruitment pattern accounting for an increase of muscle volume during exercise.

Another limitation related to the unknown muscle volume engaged during exercise is the lack of accuracy and specificity of NIRS measurements in contracting skeletal muscle. Specifically, the limitation of using NIRS technique to evaluate $\mathrm{StO}_{2 m}$ in skeletal muscle is its lack of discriminatory power to distinguish among the relative contributions of skin, adipose tissue, ${ }^{43}$ capillaries, and small arterioles and venules to the NIRS signal obtained from an uncertain volume of the region investigated. Therefore, the absolute values may be misleading with respect to the rate of adjustment of oxidative metabolism. Changes in capillary blood volume can affect the concentrations of oxygenated and deoxygenated hemoglobin measured by NIRS and cause variability in the evaluation of oxygen consumption. ${ }^{10,18}$ Another potential source of interference is the relative contribution of $\mathrm{Hb}$ and $\mathrm{Mb}^{44,60}$ to the NIRS signal. Most studies focus on $\mathrm{Hb}$ changes, since it has been reported that intracellular $\mathrm{Mb}$ accounts for less than $10 \%$ of the total NIRS signal. ${ }^{28}$ Currently, available NIRS instrumentation cannot accurately determine the relative contribution of myoglobin $(\mathrm{Mb})$ to the total NIRS signal.

\section{Future Directions}

The complexity of the model required in future developments depends on the experimental information available and hypotheses to be tested. The validity of model simulations depends on the accuracy and precision associated with estimating unknown parameters. In modeling the linkage between whole body, tissue, and cellular processes with mass balances, the analysis of dynamic responses depends on the estimated volumes of the tissues.

In practice, if the observation scale is reduced to the microvascular level, the volume of perfused tissue under consideration is uncertain. Furthermore, the spatial distribution and temporal variation of blood flow and oxygen concentration can have a significant effect on the interpretation of the measurements. ${ }^{48}$ With appropriate experimental data, more general detailed models, ${ }^{5,6,17,22}$ can take into account (a) spatial distribution of transport and reaction processes in the capillaries and extra-vascular tissue, (b) intracellular compartmentation, ${ }^{46}$ and (c) structural and metabolic characteristics of the tissue (e.g., muscle fiber types). Specifically, for human studies of skeletal muscle metabolism in response to exercise, improvements in the analysis of pulmonary and muscle oxygen dynamics could be made by experiments that simultaneously combine invasive and non-invasive techniques. ${ }^{18,28,29,39,50,59}$ The variables to be measured are venous oxygen content, muscle blood flow, and muscle oxygenation during exercise. Measurements of muscle oxygen utilization should be as close as possible to the site of cellular respiration in order to assess the dynamics of oxidative phosphorylation in vivo during exercise. Measurements of ${ }^{31} \mathrm{P}$ and ${ }^{17} \mathrm{O}$ by magnetic resonance spectroscopy could provide key species concentrations in oxidative phosphorylation. ${ }^{16}$

Nowadays measurements of pulmonary oxygen uptake, $\mathrm{VO}_{2 \mathrm{p}}$ are used to make inferences on the bioenergetic processes involved during exercise. The $\mathrm{VO}_{2 \mathrm{p}}$ average measured in our population at the end of constant work rate exercise may be expressed as percent of the maximal pulmonary oxygen uptake. ${ }^{42}$ : $49 \pm 11 \%, 68 \pm 9 \%$ and $87 \pm 6 \%$ at moderate, heavy and very heavy exercise intensity, respectively.

Presence of the slow component was discernable from our data during heavy and very heavy intensity 
exercise. To date, there is no unequivocal explanation for such behavior because several factors can lead to an excess $\mathrm{VO}_{2 \mathrm{p}}$ during high intensity constant work rate exercise, as already reported by several authors. ${ }^{4,20,21,52}$ The predominant portion of the slow component $(86 \%)$ may be associated with the contracting muscles, ${ }^{51}$ whereas fiber recruitment at higher level may affect the pattern of $\mathrm{VO}_{2 p}$ measured at the mouth. Fiber recruitment may only contribute in part to the slow component. The model developed here does not incorporate components that may lead to a slow component for $\mathrm{VO}_{2}$; however, it can be enhanced to enable testing of putative mechanisms resulting in excess oxygen consumption during high intensity exercise.

Additionally, if dynamic measurements of $\mathrm{O}_{2}, \mathrm{CO}_{2}$, and $\mathrm{pH}$ were obtained in the venous blood perfusing the contracting muscle, then the effect of acid-base regulation ${ }^{1,17}$ could be modeled to investigate the control of respiration during exercise. Although direct in vivo measurements of $\mathrm{UO}_{2 \mathrm{~m}}$ are not feasible during exercise involving a large muscle mass, indirect evaluation of $\mathrm{UO}_{2 \mathrm{~m}}$ can be achieved with a multi-scale systems biology approach. This would combine computational modeling and simulation with experimental data with many types of measurements at the whole body, tissue, and cellular levels.

\section{APPENDIX I}

The oxygen mass balances of Eqs. (1) and (2) require a relationship between total oxygen $\left(C_{\mathrm{cap}}^{\mathrm{T}}, C_{\text {tis }}^{\mathrm{T}}\right)$ to free oxygen $\left(C_{\mathrm{cap}}^{\mathrm{F}}, C_{\mathrm{tis}}^{\mathrm{F}}\right)$ in the capillaries and tissues. ${ }^{42}$ To relate the total oxygen concentration $C_{\mathrm{x}}^{\mathrm{T}}$ to free oxygen concentration $C_{\mathrm{x}}^{\mathrm{F}}(x=\operatorname{art}$, cap, tis), we consider oxygen in free and (hemoglobin) bound forms in arterial and capillary blood $\left(C_{\mathrm{art}}^{\mathrm{F}}, C_{\mathrm{cap}}^{\mathrm{B}} ; C_{\mathrm{cap}}^{\mathrm{F}}, C_{\mathrm{art}}^{\mathrm{B}}\right)$ and in free and (myoglobin) bound forms in muscle tissue $\left(C_{\mathrm{tis}}^{\mathrm{F}}, C_{\mathrm{tis}}^{\mathrm{B}}\right)$. The total oxygen concentrations in arterial and capillary blood and in muscle tissue are the sums of the corresponding free and bound oxygen concentration as:

$$
C_{\mathrm{x}}^{\mathrm{T}}=C_{\mathrm{x}}^{\mathrm{F}}+C_{\mathrm{x}}^{\mathrm{B}} \quad \mathrm{x} \in\{\text { art, cap, tis }\}
$$

which are related by local chemical equilibrium. In blood the relation is

$$
C_{\text {cap }}^{\mathrm{B}}=4 \mathrm{Hct} C_{\mathrm{rbc}, \mathrm{Hb}} S_{\mathrm{cap}, \mathrm{Hb}}=4 \mathrm{Hct} C_{\mathrm{rbc}, \mathrm{Hb}} \frac{K_{\mathrm{Hb}}\left(C_{\text {cap }}^{\mathrm{F}}\right)^{n}}{1+K_{\mathrm{Hb}}\left(C_{\mathrm{cap}}^{\mathrm{F}}\right)^{n}}
$$

In tissue the relation is

$$
C_{\mathrm{tis}}^{\mathrm{B}}=W_{\mathrm{mc}} C_{\mathrm{mc}, \mathrm{Mb}} S_{\mathrm{tis}, \mathrm{Mb}}=W_{\mathrm{mc}} C_{\mathrm{mc}, \mathrm{Mb}} \frac{K_{\mathrm{Mb}} C_{\mathrm{tis}}^{\mathrm{F}}}{1+K_{\mathrm{Mb}} C_{\mathrm{tis}}^{\mathrm{F}}}
$$

These relations depend on $\mathrm{Hb}$ and $\mathrm{Mb}$ concentrations in red blood cell and myocyte $\left(C_{\mathrm{rbc}, \mathrm{Hb}}, C_{\mathrm{mc}, \mathrm{Mb}}\right)$ and their respective volume fractions (Hct, $W_{\mathrm{mc}}$ ) and oxygen saturations ( $\left.S_{\mathrm{cap}, \mathrm{Hb}}, S_{\mathrm{tis}, \mathrm{Mb}}\right)$. From (A.1), we get the differential relationships:

$$
d C_{\mathrm{x}}^{\mathrm{T}}=d\left[C_{\mathrm{x}}^{\mathrm{F}}+C_{\mathrm{x}}^{\mathrm{B}}\right]=\left[1+d C_{\mathrm{x}}^{\mathrm{B}} / d C_{\mathrm{x}}^{\mathrm{F}}\right] d C_{\mathrm{x}}^{\mathrm{F}}=\gamma_{\mathrm{x}} d C_{\mathrm{x}}^{\mathrm{F}}
$$

where

$$
\begin{aligned}
& \gamma_{\text {cap }}=1+\frac{4 \mathrm{Hct} C_{\mathrm{rbc}, \mathrm{Hb}} K_{\mathrm{Hb}} n\left(C_{\mathrm{cap}}^{\mathrm{F}}\right)^{n-1}}{\left[1+K_{\mathrm{Hb}}\left(C_{\mathrm{cap}}^{\mathrm{F}}\right)^{n}\right]^{2}} ; \\
& \gamma_{\text {tis }}=1+\frac{W_{\mathrm{mc}} C_{\mathrm{mc}, \mathrm{Mb}} K_{\mathrm{Mb}}}{\left[1+K_{\mathrm{Mb}} C_{\mathrm{tis}}^{\mathrm{F}}\right]^{2}}
\end{aligned}
$$

Using the relationships above, Eq. (1) can be expressed as:

$\frac{d C_{\mathrm{cap}}^{\mathrm{F}}}{d t}=\frac{Q_{\mathrm{m}}\left(C_{\mathrm{art}}^{\mathrm{T}}\left(C_{\mathrm{art}}^{\mathrm{F}}\right)-C_{\text {cap }}^{\mathrm{T}}\left(C_{\mathrm{cap}}^{\mathrm{F}}\right)\right)-\mathrm{PS}_{\mathrm{cap}}\left(C_{\mathrm{cap}}^{\mathrm{F}}-C_{\text {tis }}^{\mathrm{F}}\right)}{\gamma_{\text {cap }} V_{\text {cap }}}$

Similarly, we can express Eq. (2) as

$$
\frac{d C_{\mathrm{tis}}^{\mathrm{F}}}{d t}=\frac{\operatorname{PS}\left(C_{\text {cap }}^{\mathrm{F}}-C_{\text {tis }}^{\mathrm{F}}\right)-\mathrm{UO}_{2 \mathrm{~m}}}{\gamma_{\text {tis }} V_{\text {tis }}}
$$

It should be noted that this spatially lumped, two-compartment model of oxygen transport and metabolism simulates the dynamic changes of oxygen concentration in capillary blood and tissue cells within the skeletal muscle during exercise assuming perfect mixing. Thus, under this assumption, $C_{\text {cap }}^{\mathrm{F}}(t)$ is equivalent to the free oxygen concentration at the end of the capillary, as well as to the venous oxygen concentration.

\section{APPENDIX II}

The values of the concentrations under steady-state conditions at any exercise condition $\mathrm{j}$ must satisfy the following equations:

$$
0=Q_{\mathrm{m}}^{\mathrm{j}}\left(C_{\text {art }}^{\mathrm{T}}-C_{\text {cap }}^{\mathrm{T}, \mathrm{j}}\left(C_{\text {cap }}^{\mathrm{F}, \mathrm{j}}\right)\right)-\mathrm{PS}^{\mathrm{j}}\left(C_{\text {cap }}^{\mathrm{F}, \mathrm{j}}-C_{\text {tis }}^{\mathrm{F}, \mathrm{j}}\right)
$$




$$
\begin{gathered}
0=\operatorname{PS}^{\mathrm{j}}\left(C_{\text {cap }}^{\mathrm{F}, \mathrm{j}}-C_{\mathrm{tis}}^{\mathrm{F}, \mathrm{j}}\right)-\mathrm{UO}_{2 \mathrm{~m}}^{\mathrm{j}} \\
0=\beta \phi_{\mathrm{OxPhos}}\left(C_{\mathrm{ADP}}^{\mathrm{j}}, C_{\mathrm{tis}}^{\mathrm{F}, \mathrm{j}}\right)-\phi_{\mathrm{ATPase}}\left(C_{\mathrm{ADP}}^{\mathrm{j}}\right) \\
0=\phi_{\mathrm{CK}}^{\mathrm{r}}\left(C_{\mathrm{ADP}}^{\mathrm{j}}, C_{\mathrm{ATP}}^{\mathrm{j}}, C_{\mathrm{Cr}}^{\mathrm{j}}, C_{\mathrm{PCr}}^{\mathrm{j}}\right) \\
-\phi_{\mathrm{CK}}^{\mathrm{f}}\left(C_{\mathrm{ADP}}^{\mathrm{j}}, C_{\mathrm{ATP}}^{\mathrm{j}}, C_{\mathrm{Cr}}^{\mathrm{j}}, C_{\mathrm{PCr}}^{\mathrm{j}}\right) \\
C_{\mathrm{A}, \mathrm{tot}}=C_{\mathrm{ADP}}^{\mathrm{j}}+C_{\mathrm{ATP}}^{\mathrm{j}} \\
C_{\mathrm{Cr}, \text { tot }}=C_{\mathrm{Cr}}^{\mathrm{j}}+C_{\mathrm{PCr}}^{\mathrm{j}}
\end{gathered}
$$

These 6 equations involve eight concentrations. Therefore, for any $\mathrm{j}$ we can specify two concentrations and solve for the other six. At rest, $\mathrm{j}=\mathrm{R}$, we can specify $C_{\mathrm{ATP}}^{\mathrm{R}}$ and $C_{\mathrm{Cr} \text {,tot }}$, then solve for the other concentrations including $C_{\mathrm{A}, \text { tot }}$. Under the warm-up conditions, $\mathrm{j}=\mathrm{W}$, we can specify $C_{\mathrm{A} \text {,tot }}$ and $C_{\mathrm{Cr} \text {,tot }}$ then solve for the other concentrations including $C_{\text {cap }}^{\mathrm{F}, \mathrm{W}}$, $C_{\text {tis }}^{\mathrm{F}, \mathrm{W}}, C_{\mathrm{ATP}}^{\mathrm{W}}$ and $C_{\mathrm{PCr}}^{\mathrm{W}}$.

\section{ACKNOWLEDGMENTS}

We thank Dr. Asit K. Saha for providing thoughtful and constructive criticisms. This research was supported by the grant GM-66309-01 from the National Institute for General Medical Science (NIGMS) of the National Institute of Health (NIH) for establishing the Center for Modeling Integrated Metabolic Systems (MIMS) at Case Western Reserve University.

\section{REFERENCES}

\footnotetext{
${ }^{1}$ Andreassen, S., and S. E. Rees. Mathematical models of oxygen and carbon dioxide storage and transport: interstitial fluid and tissue stores and whole-body transport. Crit. Rev. Biomed. Eng. 33:265-298, 2005.

${ }^{2}$ Balaban, R. S. Myocardial energy metabolism in health and disease cardiac energy metabolism homeostasis: role of cytosolic calcium. J. Mol. Cell. Cardiol. 34:1259-1271, 2002.

${ }^{3}$ Barstow, T. J., S. Buchthal, S. Zanconato, and D. M. Cooper. Muscle energetics and pulmonary oxygen uptake kinetics during moderate exercise. J. Appl. Physiol. 77:1742-1749, 1994.

${ }^{4}$ Barstow, T. J., A. M. Jones, P. H. Nguyen, and R. Casaburi. Influence of muscle fiber type and pedal frequency on oxygen uptake kinetics of heavy exercise. J. Appl. Physiol. 81:1642-1650, 1996.

${ }^{5}$ Beard, D. A., and J. B. Bassingthwaighte. Modeling advection and diffusion of oxygen in complex vascular networks. Ann. Biomed. Eng. 29:298-310, 2001.
}

${ }^{6}$ Beard, D. A., K. A. Schenkman, and E. O. Feigl. Myocardial oxygenation in isolated hearts predicted by an anatomically realistic microvascular transport model. Am. J. Physiol. Heart Circ. Physiol. 285:H1826-H1836, 2003.

${ }^{7}$ Behnke, B. J., C. A. Kindig, P. McDonough, D. C. Poole, and W. L. Sexton. Dynamics of microvascular oxygen pressure during rest-contraction transition in skeletal muscle of diabetic rats. Am. J. Physiol. Heart. Circ. Physiol. 283:H926-H932, 2002.

${ }^{8}$ Behnke, B. J., P. McDonough, T. I. Musch, D. C. Poole, and R. Arena. Comparison of oxygen uptake on-kinetics calculations in heart failure. Med. Sci. Sports Exerc. 35:708-709, 2003.

${ }^{9}$ Behnke, B. J., P. McDonough, D. J. Padilla, T. I. Musch, and D. C. Poole. Oxygen exchange profile in rat muscles of contrasting fibre types. J. Physiol. 549:597-605, 2003.

${ }^{10}$ Binzoni, T., W. Colier, E. Hiltbrand, L. Hoofd P. Cerretelli. Muscle $\mathrm{O}_{2}$ consumption by NIRS: a theoretical model. J. Appl. Physiol. 87:683-688, 1999.

${ }^{11}$ Caldwell, J. H., G. V. Martin, G. M. Raymond, and J. B. Bassingthwaighte. Regional myocardial flow and capillary permeability-surface area products are nearly proportional. Am. J. Physiol. 267:H654-H666, 1994.

${ }^{12}$ Chance, B., D. Jamieson, and H. Coles. Energy-linked pyridine nucleotide reduction: inhibitory effects of hyperbaric oxygen in vitro and in vivo. Nature 206:257-263, 1965.

${ }^{13}$ Chance, B., J. S. Leigh Jr, J. Kent, K. Mccully, S. Nioka, B. J. Clarkii, J. M. Maris, and T. Graham. Multiple controls of oxidative metabolism in living tissues as studied by phosphorus magnetic resonance. Proc. Natl. Acad. Sci. USA 83:9458-9462, 1986.

${ }^{14}$ Chance, B., and G. R. Williams. Respiratory enzymes in oxidative phosphorylation. I kinetics of oxygen utilization. J. Biol. Chem. 217:383-394, 1955.

${ }^{15}$ Chance, B., G. R. Williams, W. F. Holmes, and J. Higgins. Respiratory enzymes in oxidative phosphorylation. V A mechanism for oxidative phosphorylation. J. Biol. Chem. 217:439-452, 1955.

${ }^{16}$ Chung, Y., P. A. Mole, N. Sailasuta, T. K. Tran, R. Hurd, and T. Jue. Control of respiration and bioenergetics during muscle contraction. Am. J. Physiol. Cell Physiol. 288:C730C738, 2005.

${ }^{17}$ Dash, R. K., and J. B. Bassingthwaighte. Simultaneous blood-tissue exchange of oxygen, carbon dioxide, bicarbonate, and hydrogen ion. Ann. Biomed. Eng. 34:11291148, 2006.

${ }^{18}$ DeLorey, D. S., J. M. Kowalchuk, and D. H. Paterson. Relationship between pulmonary $\mathrm{O}_{2}$ uptake kinetics and muscle deoxygenation during moderate-intensity exercise. J. Appl. Physiol. 95:113-120, 2003.

${ }^{19}$ Dennis, J. E., D. M. Gay, and R. E. Welsch. An adaptive non linear least squares algorithm. ACM, Trans. Math. Software 7:348-383, 1981.

${ }^{20}$ Engelen, M., J. Porszasz, M. Riley, K. Wasserman, K. Maehara, and T. J. Barstow. Effects of hypoxic hypoxia on $\mathrm{O}_{2}$ uptake and heart rate kinetics during heavy exercise. J. Appl. Physiol. 81:2500-2508, 1996.

${ }^{21}$ Gaesser, G. A., and D. C. Poole. The slow component of oxygen uptake kinetics in humans. Exerc. Sport. Sci. Rev. 24:35-71, 1996.

${ }^{22}$ Goldman, D., and A. S. Popel. Computational modeling of oxygen transport from complex capillary networks. Relation to the microcirculation physiome. Adv. Exp. Med. Biol. 471:555-563, 1999. 
${ }^{23}$ Grassi, B. Regulation of oxygen consumption at exercise onset: is it really controversial?. Exerc. Sport Sci. Rev. 29:134-138, 2001.

${ }^{24}$ Grassi, B., L. B. Gladden, M. Samaja, C. M. Stary, and M. C. Hogan. Faster adjustment of $\mathrm{O}_{2}$ delivery does not affect $\mathrm{VO}_{2}$ on-kinetics in isolated in situ canine muscle. J. Appl. Physiol. 85:1394-1403, 1998.

${ }^{25}$ Grassi, B., L. B. Gladden, C. M. Stary, P. D. Wagner, and M. C. Hogan. Peripheral $\mathrm{O}_{2}$ diffusion does not affect $\mathrm{VO}_{2}$ on-kinetics in isolated in-situ canine muscle. J. Appl. Physiol. 85:1404-1412, 1998.

${ }^{26}$ Grassi, B., M. C. Hogan, P. L. Greenhaff, J. J. Hamann, K. M. Kelley, W. G. Aschenbach, D. Constantin, and B. L. Gladden. Oxygen uptake on-kinetics in dog gastrocnemius in situ following activation of pyruvate dehydrogenase by dichloroacetate. J. Physiol. 538:195-207, 2002.

${ }^{27}$ Grassi, B., M. C. Hogan, K. M. Kelley, W. G. Aschenbach, J. J. Hamann, R. K. Evans, R. E. Patillo, and B. L. Gladden. Role of convective $\mathrm{O}_{2}$ delivery in determining $\mathrm{VO}_{2}$ on-kinetics in canine muscle contracting at peak $\mathrm{VO}_{2}$. J. Appl. Physiol. 89:1293-1301, 2000.

${ }^{28}$ Grassi, B., S. Pogliaghi, S. Rampichini, V. Quaresima, and M. Ferrari. Muscle oxygenation and pulmonary gas exchange kinetics during cycling exercise on-transitions in humans. J. Appl. Physiol. 95:149-158, 2003.

${ }^{29}$ Grassi, B., D. C. Poole, R. S. Richardson, D. R. Knight, B. K. Erickson, and P. D. Wagner. Muscle $\mathrm{O}_{2}$ uptake kinetics in humans: implications for metabolic control. J. Appl. Physiol. 80:988-998, 1996.

${ }^{30}$ Guyton, A. C., and J. E. Hall. Transport of oxygen and carbon dioxide in the blood and body fluids. In: The Textbook of Medical Physiology, 10th ed. Philadelphia: W.B., Saunders Company, 2000, pp. 463-473.

${ }^{31}$ Hindmarsh, A. C.ODEPACK a systematized collection of ode solvers. In: Scientific Computing, edited by R. S. Stepleman. Amsterdam: North Holland, 1983, pp. 55-64.

${ }^{32}$ Hinkle, P. C. P/O ratios of mitochondrial oxidative phosphorylation. Biochim. Biophys. Acta 1706:1-11, 2005.

${ }^{33}$ Honig, C. R, C. L. Odoroff, and J. L. Frierson. Capillary recruitment in exercise: rate, extent, uniformity, and relation to blood flow. Am. J. Physiol. 238:H31-H42, 1980.

${ }^{34}$ Jeneson, J. A. L., H. V. Westerhoff, T. R. Brown, C. J. A. Van Echteld, and R. Berger. Quasi-linear relationship between Gibbs free energy of ATP hydrolysis and power output in human forearm muscle. Am. J. Physiol. 268:C1474-C1484, 1995.

${ }^{35}$ Jeneson, J. A. L., R. W. Wiseman, H. V. Westerhoff, and M. J. Kushmerick. The signal transduction function for oxidative phosphorylation is at least second order in ADP. J. Biol. Chem. 271:27995-27998, 1996.

${ }^{36}$ Jue, T., T. K. Tran, P. Mole, Y. Chung, N. Sailasuta, R. Hurd, U. Kreutzer, and S. Kuno. Myoglobin and $\mathrm{O}_{2}$ consumption in exercising human gastrocnemius muscle. Adv. Exp. Med. Biol. 471:289-294, 1999.

${ }^{37} \mathrm{Kemp}, \mathrm{G}$. Kinetics of muscle oxygen use, oxygen content, and blood flow during exercise. J. Appl. Physiol. 99:24632468, 2005.

${ }^{38}$ Knight, D. R., D. C. Poole, M. C. Hogan, D. E. Bebout, and P. D. Wagner. Effect of inspired $\mathrm{O}_{2}$ concentration on leg lactate release during incremental exercise. J. Appl. Physiol. 81:246-251, 1996.

${ }^{39}$ Knight, D. R., D. C. Poole, W. Schaffartzik, H. J. Guy, R. Prediletto, M. C. Hogan, and P. D. Wagner. Relationship between body and leg $\mathrm{VO}_{2}$ during maximal cycle ergometry. J. Appl. Physiol. 73:1114-1121, 1992.
${ }^{40}$ Korzeniewski, B. Regulation of ATP supply in mammalian skeletal muscle during resting state intensive work transition. Biophys. Chem. 83:19-34, 2000.

${ }^{41}$ Kushmerick, M. J. Energy balance in muscle activity: simulations of ATPase coupled to oxidative phosphorylation and to creatine kinase. Comp. Biochem. Physiol. B. Biochem. Mol. Biol. 120:109-123, 1998.

${ }^{42}$ Lai, N., R. K. Dash, M. M. Nasca, G. M. Saidel, and M. E. Cabrera. Relating pulmonary oxygen uptake to muscle oxygen consumption at exercise onset: in vivo and in silico studies. Eur. J. Appl. Physiol. 97:380-394, 2006.

${ }^{43}$ Lin, L., M. Niwayama, T. Shiga, N. Kudo, M. Takahashi, and K. Yamamoto. Influence of a fat on muscle oxygenation measurement using near-IR spectroscopy: quantitative analysis based on two-layered phantom experiments and Monte Carlo simulation. Front. Med. Biol. Eng. 10:4358, 2000.

${ }^{44}$ Mancini, D. M., L. Bolinger, H. Li, K. Kendrick, B. Chance, and J. R. Wilson. Validation of near-infrared spectroscopy in humans. J. Appl. Physiol. 77:2740-2747, 1994.

${ }^{45}$ Nelson, D., and M. Cox. Lehninger Principles of Biochemistry 3rd ed. New York: Worth Publishers, 2000.

${ }^{46}$ Ovadi, J., and V. Saks. On the origin of intracellular compartmentation and organized metabolic systems. Mol. Cell Biochem. 256-257:5-12, 2004.

${ }^{47}$ Ozyener, F., H. B. Rossiter, S. A. Ward, and B. J. Whipp. Influence of exercise intensity on the on- and off-transient kinetics of pulmonary oxygen uptake in humans. J. Physiol. 533:891-902, 2001.

${ }^{48}$ Pittman, R. N. Oxygen supply to contracting skeletal muscle at the microcirculatory level: diffusion vs. convection. Acta Physiol. Scand. 168:593-602, 2000.

${ }^{49}$ Poole, D. C. $\mathrm{VO}_{2}$ kinetics in COPD patients under hyperoxic conditions. J. Appl. Physiol. 80:1070-1072, 1996.

${ }^{50}$ Poole, D. C., G. A. Gaesser, M. C. Hogan, D. R. Knight, and P. D. Wagner. Pulmonary and leg $\mathrm{VO}_{2}$ during submaximal exercise: implications for muscular efficiency. $J$. Appl. Physiol. 72:805-810, 1992.

${ }^{51}$ Poole, D. C., W. Schaffartzik, D. R. Knight, T. Derion, B. Kennedy, H. J. Guy, R. Prediletto, and P. D. Wagner. Contribution of exercising legs to the slow component of oxygen uptake kinetics in humans. J. Appl. Physiol. 71:1245-1260, 1991.

${ }^{52}$ Pringle, J. S. M., J. H. Doust, H. Carter, K. Tolfrey, I. T. Campbell, and A. M. Jones. Oxygen uptake kinetics during moderate, heavy and severe intensity 'submaximal' exercise in humans: the influence of muscle fibre type and capillarisation. Eur. J. Appl. Physiol. 89:289-300, 2003.

${ }^{53}$ Rossiter, H. B., S. A. Ward, V. L. Doyle, F. A. Howe, J. R. Griffiths, and B. J. Whipp. Inferences from pulmonary $\mathrm{O}_{2}$ uptake with respect to intramuscular [phosphocreatine] kinetics during moderate exercise in humans. J. Physiol. 518:921-932, 1999.

${ }^{54}$ Rossiter, H. B., S. A. Ward, F. A. Howe, J. M. Kowalchuk, J. R. Griffiths, and B. J. Whipp. Dynamics of intramuscular 31P-MRS Pi peak splitting and the slow components of $\mathrm{PCr}$ and $\mathrm{O}_{2}$ uptake during exercise. J. Appl. Physiol. 93:2059-2069, 2002.

${ }^{55}$ Rossiter, H. B., S. A. Ward, J. M. Kowalchuk, F. A. Howe, J. R. Griffiths, and B. J. Whipp. Effects of prior exercise on oxygen uptake and phosphocreatine kinetics during highintensity knee-extension exercise in humans. J. Physiol. 537:291-303, 2001. 
${ }^{56}$ Salway, J. G. Metabolism at a Glance. 3rd ed. Blackwell Publishing Professional, 2004.

${ }^{57}$ Teague, W. E. Jr, and G. P. Dobson. Effect of temperature on the creatine kinase equilibrium. J. Biol. Chem. 267:14084-14093, 1992.

${ }^{58}$ Territo, P. R., S. A. French, M. C. Dunleavy, F. J. Evans, and R. S. Balaban. Calcium activation of heart mitochondrial oxidative phosphorylation. J. Biol. Chem. 276:2586-2599, 2001.

${ }^{59}$ Tordi, N., L. Mourot, B. Matusheski, and R. L. Hughson. Measurements of cardiac output during constant exercises: comparison of two non-invasive techniques. Int. J. Sports Med. 25:145-149, 2004.

${ }^{60}$ Tran, T. K., N. Sailasuta, U. Kreutzer, R. Hurd, Y. Chung, P. Mole, S. Kuno, and T. Jue. Comparative analysis of NMR and NIRS measurements of intracellular $\mathrm{PO}_{2}$ in human skeletal muscle. Am. J. Physiol. 276:R1682-R1690, 1999.

${ }^{61}$ Tschakovsky, M. E, and R. L. Hughson. Interaction of factors determining oxygen uptake at the onset of exercise. J. Appl. Physiol. 86:1101-1113, 1999.

${ }^{62}$ Vicini, P., and M. J. Kushmerick. Cellular energetics analysis by a mathematical model of energy balance: estimation of parameters in human skeletal muscle. Am. J. Physiol. Cell Physiol. 279:C213-C224, 2000.

${ }^{63}$ Westerhoff, H. V., C. J. Van Echteld, and J. A. Jeneson. On the expected relationship between Gibbs energy of ATP hydrolysis and muscle performance. Biophys. Chem. 54:137-142, 1995.

${ }^{64}$ Whipp, B. J., and R. Casaburi. Characterizing $\mathrm{O}_{2}$ uptake response kinetics during exercise. Int. J. Sports Med. 3:9799, 1982.

${ }^{65}$ Whipp, B. J., H. B. Rossiter, S. A. Ward, D. Avery, V. L. Doyle, F. A. Howe, and J. R. Griffiths. Simultaneous determination of muscle $31 \mathrm{P}$ and $\mathrm{O}_{2}$ uptake kinetics during whole body NMR spectroscopy. J. Appl. Physiol. 86:742747, 1999.

${ }^{66}$ Whipp, B. J., S. A. Ward, and H. B. Rossiter. Pulmonary $\mathrm{O}_{2}$ uptake during exercise: conflating muscular and cardiovascular responses. Med. Sci. Sports Exerc. 37:15741585, 2005.

${ }^{67}$ Wilson, D. F., M. Erecinska, C. Drown, and I. A. Silver. Effect of oxygen tension on cellular energetics. Am. J. Physiol. 233:C135-C140, 1977.

${ }^{68}$ Wilson, D. F., M. Erecinska, C. Drown, and I. A. Silver. The oxygen dependence of cellular energy metabolism. Arch. Biochem. Biophys. 195:485-493, 1979.

${ }^{69}$ Wilson, D. F., C. S. Owen, and A. Holian. Control of mitochondrial respiration: a quantitative evaluation of the roles of cytochrome $c$ and oxygen. Arch. Biochem. Biophys. 182:749-762, 1977. 